\title{
1D modelling of hydrocarbon generation and expulsion from Oligocene Menilite source rocks in the San and Stryi rivers region (Polish and Ukrainian Carpathians)
}

\author{
Paweł KOSAKOWSKI ${ }^{1, *}$
}

1 AGH University of Science and Technology, Faculty of Geology, Geophysics and Environmental Protection, Al. Mickiewicza 30, 30-059 Kraków, Poland

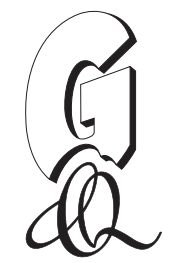

Kosakowski P. (2013) 1D modelling of hydrocarbon generation and expulsion from Oligocene Menilite source rocks in the San and Stryi rivers region (Polish and Ukrainian Carpathians). Geological Quarterly, 57 (2): 307-324, doi: 10.7306/gq.1086

Based on geochemical data of the Oligocene Menilite Shales in the Boryslav-Pokuttya, Skole (Skyba), Silesian (Krosno) and Dukla units in the Carpathians, between Krosno and Styi towns, 1D modelling of generation and expulsion processes of hydrocarbons has been carried out. These strata are characterized by mostly high organic matter content, the total organic carbon (TOC) content reaching up to $26 \mathrm{wt}$. \%. The highest hydrocarbon potential was recorded in the Boryslav-Pokuttya and Skole units. Organic matter in the Skole (Skyba) Unit is immature; in turn, in the Boryslav-Pokuttya, Silesian (Krosno) and Dukla units it is mature enough for generating hydrocarbons. Results of the modelling reveal that during the deposition of flysch in all the above mentioned Outer Carpathian units the Menilite source rocks did not reach a level of thermal maturity high enough to generate hydrocarbons. Conditions of hydrocarbon generation were obtained in the thrusting stage of the Outer Carpathians. In general, the process of hydrocarbon generation began at depths of less than $2 \mathrm{~km}$ in the Polish part, and about $4 \mathrm{~km}$ in the Ukrainian part. The kerogen transformation level reached from $10 \%$ to to complete transformation as in the Suche Rzeki IG 1 well.The results of the modelling of hydrocarbon generation and expulsion from the source rocks of all the units reveal that the highest maturity and the highest generation potential were obtained by the Menilite Shales in the Silesian and Dukla units.

Key words: Menilite Shales, Outer Carpathians, petroleum geochemistry, source rocks, petroleum generation.

\section{INTRODUCTION}

The Polish and Ukrainian Carpathian orogen belongs to one of the largest petroleum provinces of Central Europe, constituting one of the oldest petroleum-producing regions in the world (Kotarba and Peryt, 2011, with references therein). The Oligocene Menilite Shales are considered to be the most important source rock (see e.g., Kotarba and Koltun, 2005; Kotarba et al., 2007). They are a unique lithofacial unit of the Carpathian region owing to the claystone-silica character of the strata (Kotlarczyk and Leśniak, 1990) and relatively high organic matter content of up to $26 \%$ (e.g., Bessereau et al., 1996; Kotarba and Koltun, 2005; Kosakowski et al., 2009). Some results of geochemical analysis of the Menilite Shales in the Outer Carpathians have already been given by several authors (e.g., Koltun, 1992; ten Haven et al., 1993; Kruge et al., 1996; Koltun et al., 1998; Köster et al., 1998a; Kotarba et al., 2007). Nevertheless, the kinetics of kerogen transformation was investigated only by few (Curtis et al., 2004; Lewan et al., 2006).

\section{*E-mail:kosak@agh.edu.pl}

Received: January 15, 2013; accepted: March 4, 2013; first published online: April 10, 2013
This paper summarizes the geochemical characteristics of the Menilite Shales of the area located between the towns of Krosno and Stryi (Fig. 1), with special reference to its organic matter, depositional palaeoenvironment and hydrocarbon source rock assessment based on published geochemical data representing 719 samples from 28 wells and 42 exposures (Fig. 1; Matyasik, 2000; Curtis et al., 2004; Kotarba et al., 2007; Kosakowski et al., 2009). In this paper, 16 performed analyses of elemental composition were used for calculation of kinetic parameters of kerogen. Estimates of kinetic parameters were calculated using an indirect method based on organic sulfur content in kerogen (e.g., Lewan and Ruble, 2002; Lewan et al., 2006; Więcław et al., 2010).

Burial history, thermal maturity, and timing of hydrocarbon generation and expulsion were modelled for the Oliogocene Menilite Shales in the Boryslav-Pokuttya, Skole (Skyba), Silesian (Krosno) and Dukla units at 12 well locations (Fig. 1). The generation analysis was carried out by one-dimensional numerical modelling using BasinMod ${ }^{\mathrm{TM}}$.

\section{OUTLINE OF GEOLOGY}

The Carpathian Arc is a constituent of the Alpine orogenic belt (Fig. 1). The Outer Carpathians are bounded on the north and north-east by the Eastern European Platform, on the east 


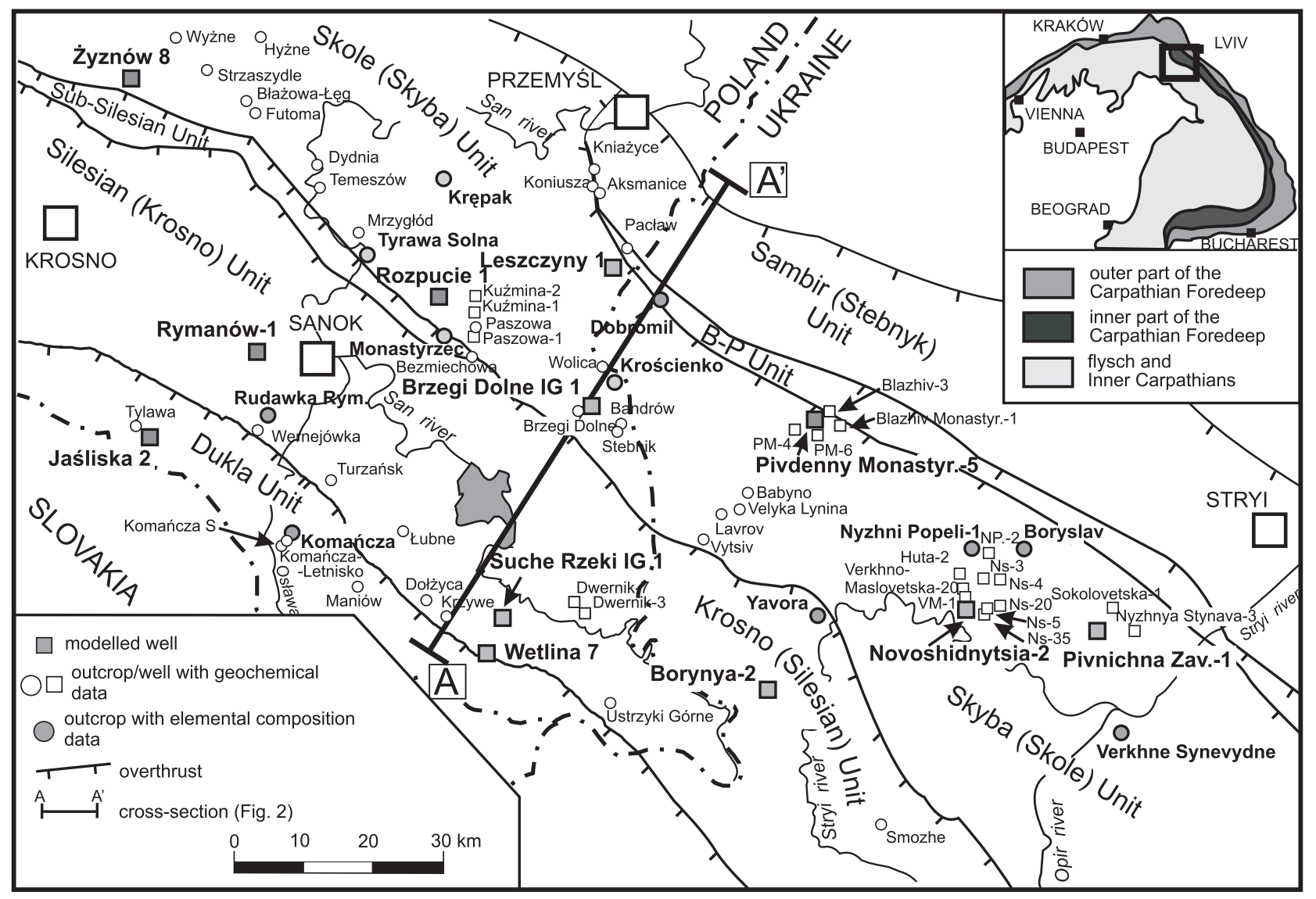

Fig. 1. Geological sketch map of the Polish and Ukrainian Carpathians in the San and Stryi rivers region showing major tectonic units and the location of rock samples and modelled wells

B.-P. Unit - Boryslav-Pokuttya Unit; A-A' - cross-section shown in Figure 2

by the Moesian Platform, and by the Inner Carpathians on the south (Oszczypko, 2006). The Outer Carpathians consist of a number of tectonic units thrust over one another forming a system of nappes (Fig. 2; Żytko, 1999).

The Polish and Ukrainian sectors of the Outer Carpathians comprise the following tectonic units (from north-east to south-west): Carpathian Foredeep, Skyba (Skole) Unit, Krosno (Silesian) Unit, Dukla Unit, Magura Unit, Marmarosh Unit and Pieniny Klippen Belt. The Carpathian Foredeep consists of three units (Vul et al., 1998). The outer, Bilche-Volytsya Unit is made up of unfolded Miocene molasse, the central Sambir Unit is represented by folded molasse, and the innermost part of the Foredeep, the Boryslav-Pokuttya Unit, includes a flysch sequence covered by molasse. The Bilche-Volytsya is the main gas-bearing unit of the Ukrainian Carpathians (Kurovets et al., 2004; Kotarba et al., 2011, with references therein), while the major oil fields in the area occur in the Boryslav-Pokuttya Unit.

The flysch succession of the Carpathians is mainly represented by Lower Cretaceous to Lower Miocene siliciclastic rocks. It comprises two main organic-rich intervals - the Lower Cretaceous Shypot and Spas Beds and the Oligocene-Lower Miocene Menilite Shales (Kotlarczyk and Leśniak, 1990; Koltun et al., 1998; Bieńkowska, 2004; Kotlarczyk et al., 2006; Sotak, 2010; Salata and Uchman, 2012). The latter represent the principal source-rock succession in both the Polish and Ukrainian Carpathians (Koltun, 1992; Lafargue et al., 1994; Koltun et al., 1998; Kotarba and Koltun, 2005), while the Lower Cretaceous rocks might also contribute to petroleum accumulations in the area.
The Menilite Shales reach their maximum thickness within the outer tectonic units, namely in the Boryslav-Pokuttya and the external part of the Skyba units. Here they are subdivided into three parts - the 250 to 500 m thick organic-rich Lower Menilite Shales (Kulchytsky, 1986; Andreyeva-Grigorovich et al., 1986), the 200 m-thick organic-lean Middle Menilite Shales, and up to 1200 m-thick organic-rich Upper Menilite Shales. As the latter occur in localized areas, just the Lower Menilite Shales represent the main source-rock level in the area and are the main subject of this study. The thickness of the Lower Menilite Shales decreases towards the more internal part of the Flysch Belt, being substituted in the inner part of the Skyba Unit and in Krosno (Silesian) Unit from their top by the organic-lean sandstones and siltstones of the Krosno Beds. Their petroleum potential decreases in the same direction (Koltun et al., 1998; Kotarba et al., 2007).

\section{BORYSLAV-POKUTTYA UNIT}

The Boryslav-Pokuttya Unit is composed of several superimposed nappes, each of them comprising the Upper Cretaceous to Lower Miocene flysch succession covered by Miocene molasse (Fig. 2). This peculiar structure provides favourable conditions for both petroleum formation and accumulation. Owing to the complex overthrust structure, the organic-rich Menilite Shales occur at a wide range of depths, from the surface to depths exceeding $8 \mathrm{~km}$, which covers the whole "oil window". The multiple sandstone beds and faults serve as migration 


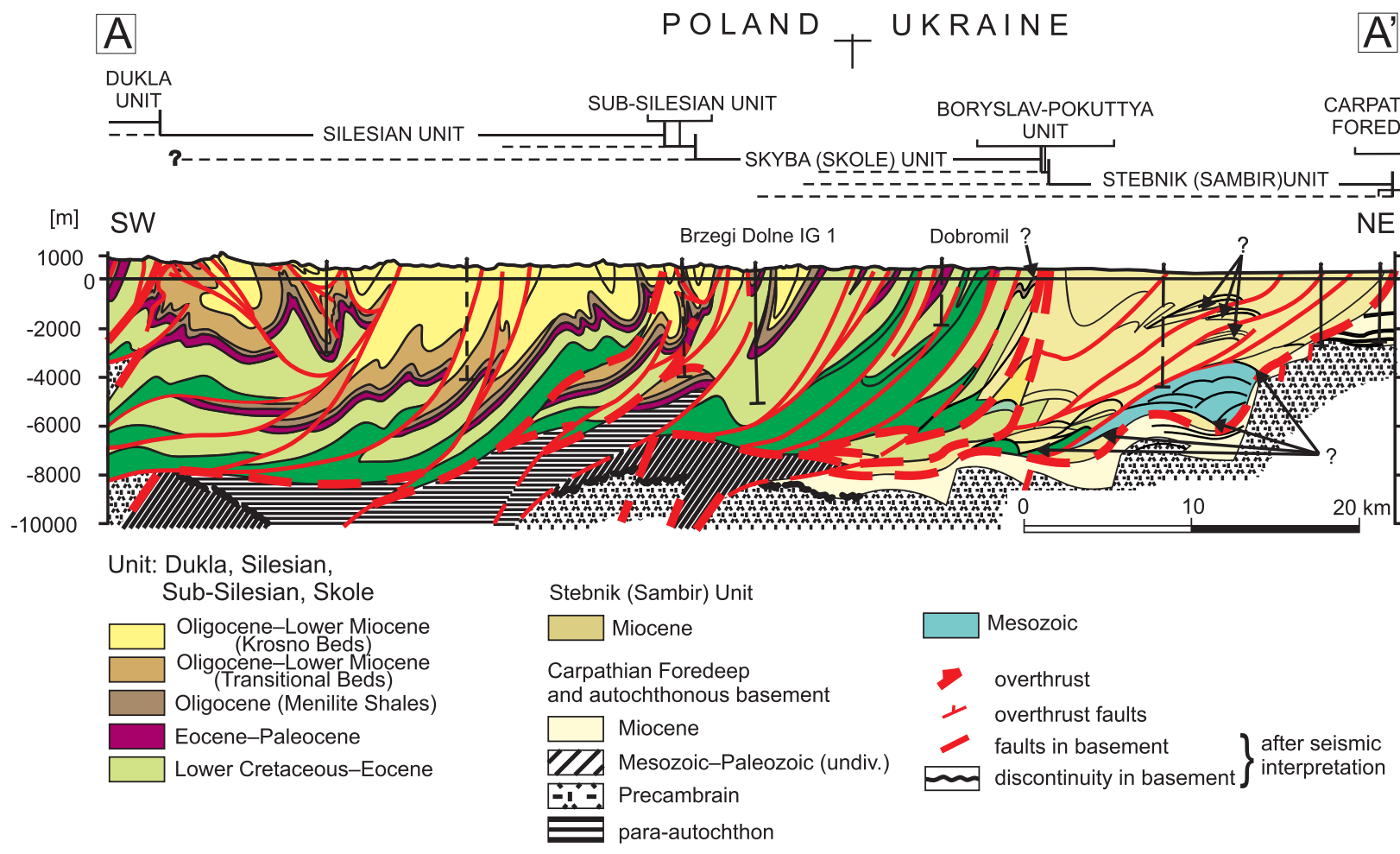

Fig. 2. Geological cross-section through the Polish and Ukrainian Carpathians (Maćkowski et al., 2009; Kuśmierek, 2010, modified)

pathways, thick sandstones in the flysch succession as the reservoirs, while folds form suitable traps. Multiple shale beds as well as salt-bearing molasse deposits seal the petroleum accumulations. For these reasons the Boryslav-Pokuttya Unit is especially interesting for petroleum generation modelling.

\section{SKOLE (SKYBA) UNIT}

The external part of this unit is stratigraphically similar to the Boryslav-Pokuttya Unit, differing from it by the presence of Lower Cretaceous beds in its flysch succession (Fig. 2). However, the lack of the complex of superimposed nappes and of the molasse succession makes it less suitable for petroleum formation and accumulation. Nonetheless, the existence of oil fields in this unit proves its petroleum potential, especially in view of the existing fields in this unit in Poland (Karnkowski, 1999).

\section{SILESIAN (KROSNO) UNIT}

Although the Krosno (Silesian) Unit differs from the previous ones by the reduced thickness and petroleum potential of the Menilite Shales, the proven gas accumulations in the Oligocene succession as well as the presence of a number of petroleum fields in this unit in Poland (Karnkowski, 1999) show the necessity of investigation of the petroleum generation processes in this area (Fig. 2).

\section{DUKLA UNIT}

The Dukla Unit is one of the most southern tectonic units of the Polish Outer Carpathians and has not yet been studied in detail because it is overlain by the Magura Unit. The stratigraphic profile of the Dukla Unit is similar to that of the Silesian Unit - from Upper Cretaceous to Oligocene (Fig. 2; e.g., Ciurej and Haczewski, 2012). However, to date, hydrocarbon accumulations have only been discovered in the Oligocene Cergowa sandstones (Karnkowski, 1999). This type of sandstone is well-documented from quarry exposures (e.g., Dirnerová et al., 2012) and occurs only in the Menilite Shales in the tectonic windows occurring in front of the Magura Unit.

\section{MATERIALS}

Results of geochemical analyses of 719 samples from 28 wells and 42 exposures from the Polish and Ukrainian parts of the Outer Carpathians have been gathered (Fig. 1). Most of the results of geochemical studies used in interpretation comes from previous works, mainly Kosakowski et al. (2009). For this paper, Rock-Eval pyrolysis of 50 rock samples and elemental analysis of 10 rock samples was performed.

From the Boryslav-Pokuttya Unit only 92 samples from the Menilite Shales were collected. Those samples were taken from frontier exposures in four exposures in the Polish part, and from the Dobromil exposure in the Ukrainian part of the Boryslav-Pokuttya Unit (Appendix 1 and Fig. 1). Additional

* Supplementary data associated with this article can be found, in the online version, at doi: 10.7306/gq.1086 
samples wre collected from 16 wells from the Ukrainian part of the Boryslav-Pokuttya Unit (Appendix 1 and Fig. 1).

A total of 390 samples has been taken from the Skole (Skyba) Unit in 16 exposures and 6 wells in Poland and 6 exposures and 2 wells in Ukraine (Appendix 1 and Fig. 1).

From the Silesian (Krosno) Unit, geochemical results of 110 samples were derived from the 9 exposures and from 3 wells in Poland and 15 samples from the Yavora and Smozhe exposures, and the Borynya-2 well in Ukraine (Appendix 1 and Fig. 1).

The Menilite Shales in the Dukla Unit were characterized using data from 57 samples from 6 exposures (Appendix 1 and Fig. 1).

\section{ANALYTICAL PROCEDURE OF ELEMENTAL ANALYSIS}

The results of geochemical analyses were derived mostly from previous studies. For the purpose of this paper only the elemental composition of dispersed organic matter $(\mathrm{O}, \mathrm{C}, \mathrm{H}, \mathrm{N}$ and S) was determined using a Carlo Erba 1108 elemental analyser. Kerogens were isolated by hydrofluoric and hydrochloric acid digestion followed by heavy liquid separation $\left(\mathrm{ZnBr}_{2}\right.$ solution, density $2.1 \mathrm{~g} / \mathrm{cm}^{3}$ ). Total iron was measured on a Perkin-Elmer Plasma 40 ICP-AES instrument after digesting the ash from the burned kerogen $\left(815^{\circ} \mathrm{C}, 30 \mathrm{~min}\right)$ with hydrochloric acid. The organic sulphur content in kerogen was calculated as the difference between total and pyritic sulphur. The oxygen content was calculated as the difference between $100 \%$ taking into account the $\mathrm{O}, \mathrm{C}, \mathrm{H}, \mathrm{N}, \mathrm{S}$, moisture and ash contents.

\section{MODELLING PROCEDURE}

Burial and thermal histories, hydrocarbon generation and expulsion were reconstructed by means of the BasinMod ${ }^{\mathrm{TM}} 1 \mathrm{D}$ computer modelling program of Platte River Associates, U.S.A. (Kosakowski et al., 2010; Kosakowski and Wróbel, 2011).

To assess the amount of generated and expelled hydrocarbons from the Menilite source rocks the following data were quantified: event definition (deposition, erosion), present and original thicknesses, lithology of strata, present gradients and palaeogradients (Maćkowski et al., 2009; Kosakowski et al., 2009). Input parameters for the modelling include geochemical data such as reconstructed TOC and kerogen type. Maturity was calculated using the EASY\%R $\mathrm{R}_{0}$ model (Sweeney and Burnham, 1990), whereas for hydrocarbon generation and expulsion modelling the LLNL model (Burnham et al., 1987) was applied. Maturity modelling was calibrated taking advantage of Rock-Eval $T_{\max }$ temperature and vitrinite reflectance $R_{0}$ data published by Koltun (1992), Matyasik (2000), Kotarba et al. (2007), Maćkowski et al. (2009) and Kosakowski et al. (2009). The kinetic parameters of kerogen $\left(E_{a}\right.$ and $\left.A_{0}\right)$ for the modelling were calculated according to procedures described by Lewan and Ruble (2002).

\section{SOURCE ROCK CHARACTERISTICS AND KINETIC PARAMETERS OF KEROGEN OF MENILITE SHALES}

Results of previous papers and new analytical data show that organic matter content usually ranges from 4 to $8 \mathrm{wt} . \%$ TOC, locally exceeding 26 wt.\% (e.g., Bessereau et al., 1996;
Kruge et al., 1996; Köster et al., 1998a; Kotarba and Koltun, 2005; Kotarba et al., 2007; Kosakowski et al., 2009), and the Menilite Shales are considered to be the main source rock for Carpathian oils (ten Haven et al., 1993; Bessereau et al., 1996; Kruge et al., 1996; Curtis et al., 2004; Kotarba et al., 2005, 2007). The petroleum potential of this formation is highest in the Boryslav-Pokuttya Unit in the Ukrainian area and in the Skole (Skyba) Unit. In the Polish part of the Silesian (Krosno) Unit, it is moderate and much lower than in its Ukrainian part, and it drops considerably in the Dukla Unit (Kotarba et al., 2007). The Menilite Shales in the study area contain varying mixtures of different types of kerogen (Koltun, 1992; Koltun et al., 1998; Curtis et al., 2004; Kotarba et al., 2006). Type II kerogen prevails, algal Type I kerogen occurs sporadically while Type III kerogen with terrestrial organic matter predominance is locally significant (Koltun et al., 1998; Köster et al., 1998b; Curtis et al., 2004; Kotarba et al., 2007). In the Skole (Skyba) Unit and in the northern part of the Silesian (Krosno) Unit the organic matter is thermally immature to marginally mature (Kotarba et al., 2007). By contrast, organic matter deposited in the Boryslav-Pokuttya and in the southern part of the Silesian (Krosno) Unit is mature (the low-temperature stage of the thermogenic process; Koltun, 1992; Kotarba and Koltun, 2005).

This paper presents the characteristics of the Menilite Shales in particular zones for which reconstruction of hydrocarbon generation and expulsion processes was carried out on the basis of calculated kinetic parameters of kerogen $\left(E_{a}\right.$ and $\left.A_{0}\right)$.

\section{BORYSLAV-POKUTTYA UNIT}

The Menilite Shales in the Boryslav-Pokuttya Unit (B-P Unit) were characterized using 33 exposure samples from its frontal part (Kniażyce-Pacław area) and 59 borehole samples from the Pivdenny Monastyrets and Novoshidnytsia-Pivnichna Zavoda areas, where the B-P Unit has been encountered under the Skyba Unit (Figs. 1 and 2). The Menilite Shales are characterized by a wide range of organic carbon content (0.84-16.0 wt.\%; Table 1). The mean value for different areas are high (4.1-4.7 wt.\%), and reach 7.6 wt.\% in the Kniażyce-Pacław area (Table 1).

Equally high variability and high mean values can be observed in the hydrocarbon content $S_{1}+S_{2}$. In the Kniażyce-Pacław area the hydrocarbon content shows a wide range, from 11.0 to $96.0 \mathrm{mg} \mathrm{HC} / \mathrm{g}$ rock with an average of $31.5 \mathrm{mg} \mathrm{HC} / \mathrm{g}$ rock (Table 1 and Fig. 3A). In the Pivdenny Monastyrets area the hydrocarbon content is a little lower, but also high, from 0.87 to $48.2 \mathrm{mg} \mathrm{HC} / \mathrm{g}$ rock, with the average equal to $18.5 \mathrm{mg} \mathrm{HC} / \mathrm{g}$ rock (Table 1 and Fig. 3A). Much higher amounts of hydrocarbons are observed in the Novoshidnytsia-Pivnichna Zavoda area, where the sum of $S_{1}+S_{2}$ reaches $74.3 \mathrm{mg} \mathrm{HC} / \mathrm{g}$ rock. Despite the wider range in the hydrocarbon content, the mean value is close to that of the Pivdenny Monastyrets area and is equal to $16.9 \mathrm{mg} \mathrm{HC} / \mathrm{g}$ rock (Table 1). Both TOC content and the hydrocarbons indicate a good and even excellent source rock quality of the Menilite Shales (Fig. 3A).

The good quality of the Menilite Shales is also shown by values of the hydrogen index $(\mathrm{HI})$. In the former area its average is $339 \mathrm{mg} \mathrm{HC} / \mathrm{g} \mathrm{TOC}$ and in the latter areas, with similar variability, it ranges from approximately 100 to over $700 \mathrm{mg} \mathrm{HC} / \mathrm{g} \mathrm{TOC}$ (Table 1 and Fig. 4A).

The $\mathrm{HI}$ indicates the presence of Type II kerogen with local admixtures of Type III kerogen (Figs. 4A and 5). The high $\mathrm{HI}$ (500-700 mg HC/g TOC) even suggests the presence of Type I kerogen. 
Rock-Eval characteristics and hydrocarbon potential of the Menilite Shales

\begin{tabular}{|l|l|l|l|}
\hline \multicolumn{1}{|c|}{ Tectonic Unit } & \multicolumn{4}{|c|}{ BORYSLAV-POKUTTYA } \\
\hline \multicolumn{1}{|c|}{ Area } & Kniażyce-Pacław & $\begin{array}{c}\text { Pivdenny } \\
\text { Monastyrets }\end{array}$ & $\begin{array}{c}\text { Novoskhidnytsya- } \\
\text { Pivnichna Zavoda }\end{array}$ \\
\hline $\begin{array}{l}\text { Total organic carbon } \\
\text { TOC [wt.\%] }\end{array}$ & $\frac{2.68 \text { to } 16.0}{7.6} \frac{(24)}{(4)}$ & $\frac{0.84 \text { to } 14.0}{4.7} \frac{(11)}{(5)}$ & $\frac{1.00 \text { to } 12.5}{7.6} \frac{(57)}{(13)}$ \\
\hline $\begin{array}{l}T_{\max } \\
{\left[{ }^{\circ} \mathrm{C}\right]}\end{array}$ & $\frac{398 \text { to } 434}{415} \frac{(24)}{(4)}$ & $\frac{415 \text { to } 438}{429} \frac{(11)}{(5)}$ & $\frac{421 \text { to } 461}{439} \frac{(57)}{(13)}$ \\
\hline $\begin{array}{l}\mathrm{S}_{2} \\
{[\mathrm{mg} \mathrm{HC/g} \text { rock] }}\end{array}$ & $\frac{10.5 \text { to } 85.0}{31.5} \frac{(24)}{(4)}$ & $\frac{0.81 \text { to } 46.8}{17.3} \frac{(11)}{(5)}$ & $\frac{0.42 \text { to } 71.9}{15.5} \frac{(57)}{(13)}$ \\
\hline $\begin{array}{l}\mathrm{S}_{1}+\mathrm{S}_{2} \\
{[\mathrm{mg} \mathrm{HC/g} \text { rock] }}\end{array}$ & $\frac{11.0 \text { to } 96.0}{32.9} \frac{(24)}{(4)}$ & $\frac{0.87 \text { to } 48.2}{18.5} \frac{(11)}{(5)}$ & $\frac{0.60 \text { to } 74.3}{16.9} \frac{(57)}{(13)}$ \\
\hline $\begin{array}{l}\text { Production index } \\
\text { (PI) }\end{array}$ & $\frac{0.01 \text { to } 0.15}{0.05} \frac{(24)}{(4)}$ & $\frac{0.02 \text { to } 0.16}{0.09} \frac{(11)}{(5)}$ & $\frac{0.02 \text { to } 0.37}{0.13} \frac{(57)}{(13)}$ \\
\hline $\begin{array}{l}\text { Hydrogen index }(\mathrm{HI}) \\
\text { [mg HC/g TOC] }\end{array}$ & $\frac{167 \text { to } 732}{402} \frac{(24)}{(4)}$ & $\frac{96 \text { to } 572}{363} \frac{(11)}{(5)}$ & $\frac{87 \text { to } 647}{314} \frac{(57)}{(13)}$ \\
\hline
\end{tabular}

$T_{\max }$ - temperature maximum of $\mathrm{S}_{2}$ peak; $\mathrm{S}_{2}$ - residual petroleum potential; range and mean value of geochemical parameters are given (number of samples in parenthesis); number of sampled sites in denominator; data after Koltun (1992), Koltun et al. (1998), Matyasik (2000), Kotarba and Koltun (2005), Kotarba et al. (2007), Więcław et al. (2008) and Kosakowski et al. (2009)

Average temperature $T_{\max }$ values $\left(415,429\right.$ and $\left.439^{\circ} \mathrm{C}\right)$ show that the organic matter is immature or in the initial phase of the "oil window" (Table 1 and Fig. 4A; Koltun et al., 1998; Kotarba et al., 2007). The elemental analysis of organic matter is consistent with such a maturity (Table 2 and Fig. 5).

In consideration of the low organic matter maturity it was assumed that TOC content did not change during transformation or changed only to a low degree. At this level of transformation, the initial TOC content is ca. 5.5 wt.\% (Table 3). The TOC。 there was assessed from correlation between residual TOC and the kerogen transformation degree as given in Cornford (1994). The TOC calculation was also supplemented with measurement of residual TOC and the atomic $\mathrm{H} / \mathrm{C}$ ratio (Baskin, 1997).

The kinetic type of organic matter was determined from organic sulphur measurements on samples from the Pivdenny Monastyrets- 5 well (Table 2). Based on these data, kinetic parameters of kerogen $\left(E_{a}\right.$ and $\left.A_{0}\right)$ were calculated (Lewan and Ruble, 2002). The low-sulphur kerogen (Hunt et al., 1991) is characterized by activation energy $E_{a}$ of $60.6 \mathrm{kcal} / \mathrm{mol}$ and $A_{o}$ of $2.69 \times 10^{29} 1 / \mathrm{Ma}$, and $55.3 \mathrm{kcal} / \mathrm{mol}$ and $4.85 \times 10^{27} 1 / \mathrm{Ma}$, in the Pivdenny Monastyrets area and the Novoshidnytsia-Pivnichna Zavoda area, respectively (Table 4).

\section{SKOLE (SKYBA) UNIT}

The Menilite Shales in the Skole Unit and their equivalents in the Ukrainian part of the Skyba Unit are much better sampled and characterized than in the remaining units of the Outer Carpathians. In total, 417 samples were collected from this unit, of which 73 samples were taken in its Ukrainian part (Table 5). In the Ukrainian part the analytical material was taken at exposures in the borderland (Fig. 1). The samples were also collected from the Vierkhno Maslovetska-1 and -20 wells. The Menilite Shales in the Skyba Unit are characterized by very high TOC (average TOC 6.7 and $9.0 \mathrm{wt} . \%$ ) and hydrocarbon contents (29.6 and $35.8 \mathrm{mg} \mathrm{HC/g}$ rock; Table 5) indicating very good and excellent source quality (Fig. 3B).
The hydrocarbon potential of those strata varies across a wide range - from 150 to $654 \mathrm{mg} \mathrm{HC/g} \mathrm{TOC}$, with an average of $343 \mathrm{mg} \mathrm{HC} / \mathrm{g}$ TOC. The oil-prone Type II kerogen prevails, with local admixtures of Type I and Type III kerogens (Figs. 4B and 5). The $T_{\max }$ values from 409 to $433^{\circ} \mathrm{C}$ ( $T_{\max }$ average $421^{\circ} \mathrm{C}$ ) indicate immaturity of the strata investigated (Table 5 and Fig. 4B). Because of the low stage of transformation it was assumed that the present TOC content is its original value ( $\mathrm{Ta}-$ ble 3). Kinetic parameters of kerogen dispersed in this region were determined for samples collected from the above mentioned exposures. Based on these data the activation energy is $52.6 \mathrm{kcal} / \mathrm{mol}$ and the pre-exponential factor is $6.63 \times 10^{26} 1 / \mathrm{Ma}$ (Table 4).

In the Polish part of the study area the Menilite Shales were collected from a large area, from Żyznów up to the Brzegi Dolne-Krościenko-Leszczyny borderland (Fig. 1).

In the Żyznów area (the Żyznów 8 well, Wyżne, Hyżne Straszydle and Futoma exposures; Fig. 1) the Menilite Shales also contain large amounts of TOC (0.7 to $17.2 \mathrm{wt} . \%$; Table 5 and Fig. 3B). The average TOC content is as high as $6.3 \mathrm{wt} . \%$. Similarly, the hydrocarbon content ranges from 1.2 to $129.7 \mathrm{mg}$ $\mathrm{HC} / \mathrm{g}$ rock, with the average of $23.5 \mathrm{mg} \mathrm{HC} / \mathrm{g}$ rock (Table 5 and Fig. 3B). The $\mathrm{HI}$ ranges from 94 to $731 \mathrm{mg} \mathrm{HC} / \mathrm{g}$ TOC (average of $318 \mathrm{mg} \mathrm{HC} / \mathrm{g} \mathrm{TOC}$ ). These values indicate the presence of Type II kerogen and a significant proportion of terrestrial Type III kerogen (Figs. 4B and 5). Organic matter in the Żyznów area is immature (average $T_{\max } 412^{\circ} \mathrm{C}$; Table 5 and Fig. 4B). Therefore, the initial TOC content did not change during transformation (Table 3). Kinetic parameters of kerogen dispersed in this area were determined for samples collected from the Żyznów 8 well and they are $53.7 \mathrm{kcal} / \mathrm{mol}$ and $1.49 \times 10^{27} 1 / \mathrm{Ma}$ (Table 4).

In the Dydnia-Paszowa area (Fig. 1) TOC contents range from 0.2 to about $15 \mathrm{wt} . \%$, with average amounts of $7.3 \mathrm{wt} . \%$ (Table 5 and Fig. 3B). A similar variability is observed in the hydrocarbon content $(0.27-80.3 \mathrm{mg} \mathrm{HC} / \mathrm{g}$ rock) and $\mathrm{HI}$ values (84-718 mg HC/g TOC; Table 5 and Figs. 3B, 4B). Mean values of the hydrocarbon content in this area are slightly lower than in the adjacent area and amount to $14.6 \mathrm{mg} \mathrm{HC} / \mathrm{g}$ rock, and those of the $\mathrm{HI}$ to $292 \mathrm{mg} \mathrm{HC} / \mathrm{g}$ TOC. The HI values indicate the pres- 

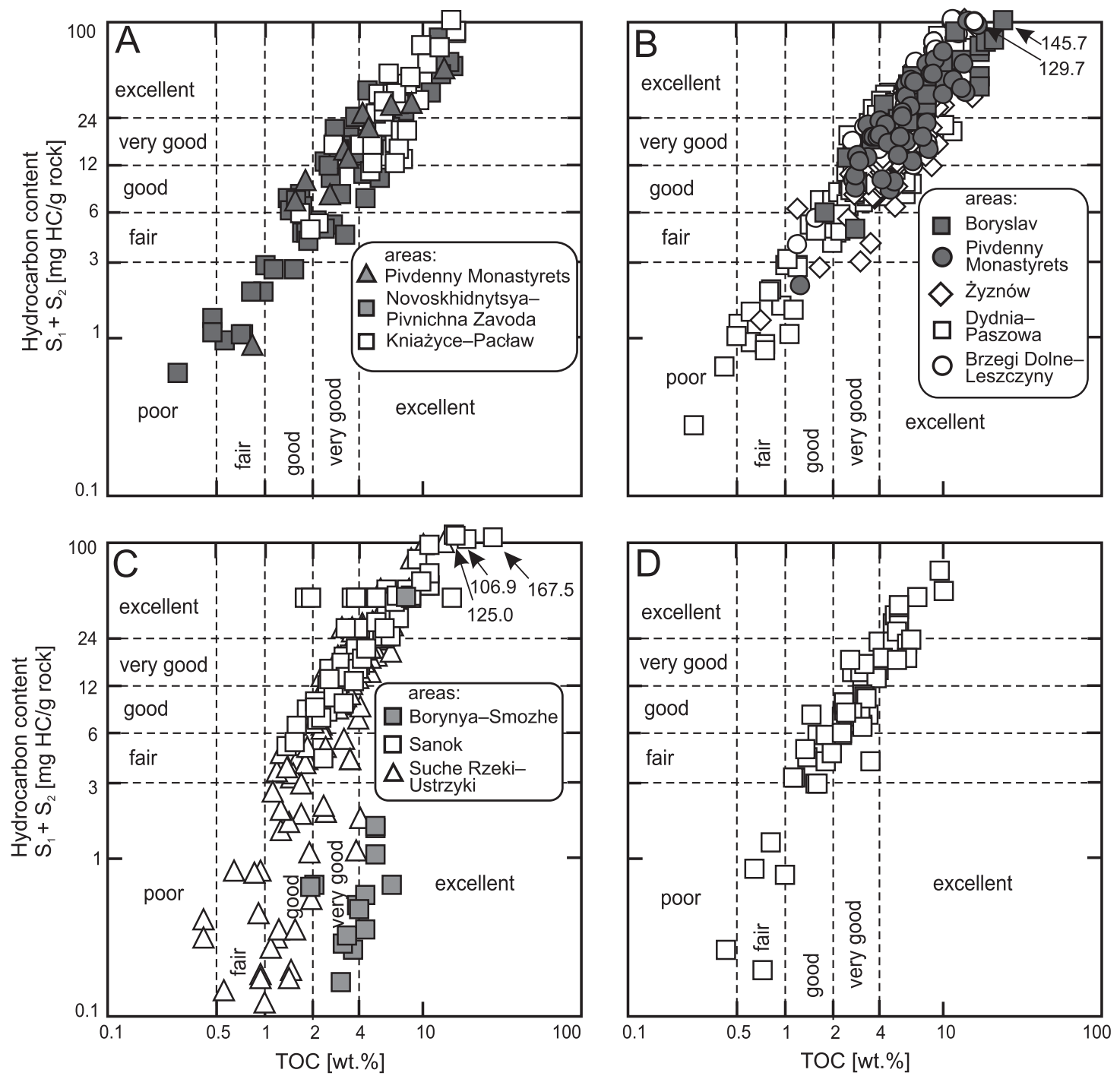

Fig. 3. Petroleum source quality diagram for Menilte Shales in the (A) Boryslav-Pokuttya Unit, (B) Skole (Skyba) Unit, (C) Silesian (Krosno) Unit and (D) Dukla Unit

Classification after Hunt (1996) and Peters and Cassa (2002)

ence of Type II kerogen with a significant proportion of terrestrial Type III kerogen (Figs. 4B and 5). Organic matter is immature or at an initial stage of low-temperature thermogenic alteration ( $T_{\max }: 406-444^{\circ} \mathrm{C}$, average $420^{\circ} \mathrm{C}$; Table 5 and Fig. 4B). Kinetic parameters of kerogen dispersed in this area were determined for samples collected from the Krępak and Tyrawa Solna exposures and from the Rozpucie 1 well. They are represented by an activation energy of $57.0 \mathrm{kcal} / \mathrm{mol}$ and a pre-exponential factor of $1.78 \times 10^{28} 1 / \mathrm{Ma}$ (Table 4).

In the Brzegi Dolne-Leszczyny area, the Menilite Shales are characterized by the best geochemical properties in the Skole Unit. The average TOC and hydrocarbon content are very high and amount to $7.9 \mathrm{wt} . \%$ and $42.3 \mathrm{mg} \mathrm{HC} / \mathrm{g}$ rock, respectively (Table 5). The $\mathrm{HI}$ ranges from 161 to $736 \mathrm{mg} \mathrm{HC} / \mathrm{g}$ TOC (average $494 \mathrm{mg} \mathrm{HC} / \mathrm{g}$ TOC), which suggests the presence of oil-prone Type II kerogen with local admixtures of Type I and Type III kerogens (Figs. 4B and 5). $T_{\text {max }}$ values from 409 to $444^{\circ} \mathrm{C}$ (average $418^{\circ} \mathrm{C}$ ) indicate a maturity level as in the other areas of the Skole Unit (Table 5 and Fig. 4B). Kinetic parameters, based on samples collected from the Krościenko exposure (Fig. 1), are: $E_{a}-50.9 \mathrm{kcal} / \mathrm{mol}$ and $A_{o}-1.84 \times 10^{26}$ 1/Ma (Table 4).

\section{SILESIAN (KROSNO) UNIT}

In the Silesian Unit the Menilite Shales were characterized in the Sanok, Suche Rzeki-Ustrzyki and Borynya-Smozhe areas (Fig. 1; Ciurej and Haczewski, 2012). In both areas the geochemical values and indices are similar (Fig. 3C). The average TOC content is 4.7 and $4.1 \mathrm{wt} . \%$, respectively (Table 6 ). There are very high maximum contents in exposure samples in the Sanok (17.3 wt.\%) and Suche Rzeki-Ustrzyki area (20.2 wt.\%; Table 6). Samples from wells typically contain lower amounts of TOC (maximum 4.2 wt.\% in the Suche Rzeki IG 1 well; Fig. 1). Likewise, wide variations in the hydrocarbon content can be observed, from 0.3 to $167.5 \mathrm{mg} \mathrm{HC} / \mathrm{g}$ rock in the later, with aver- 

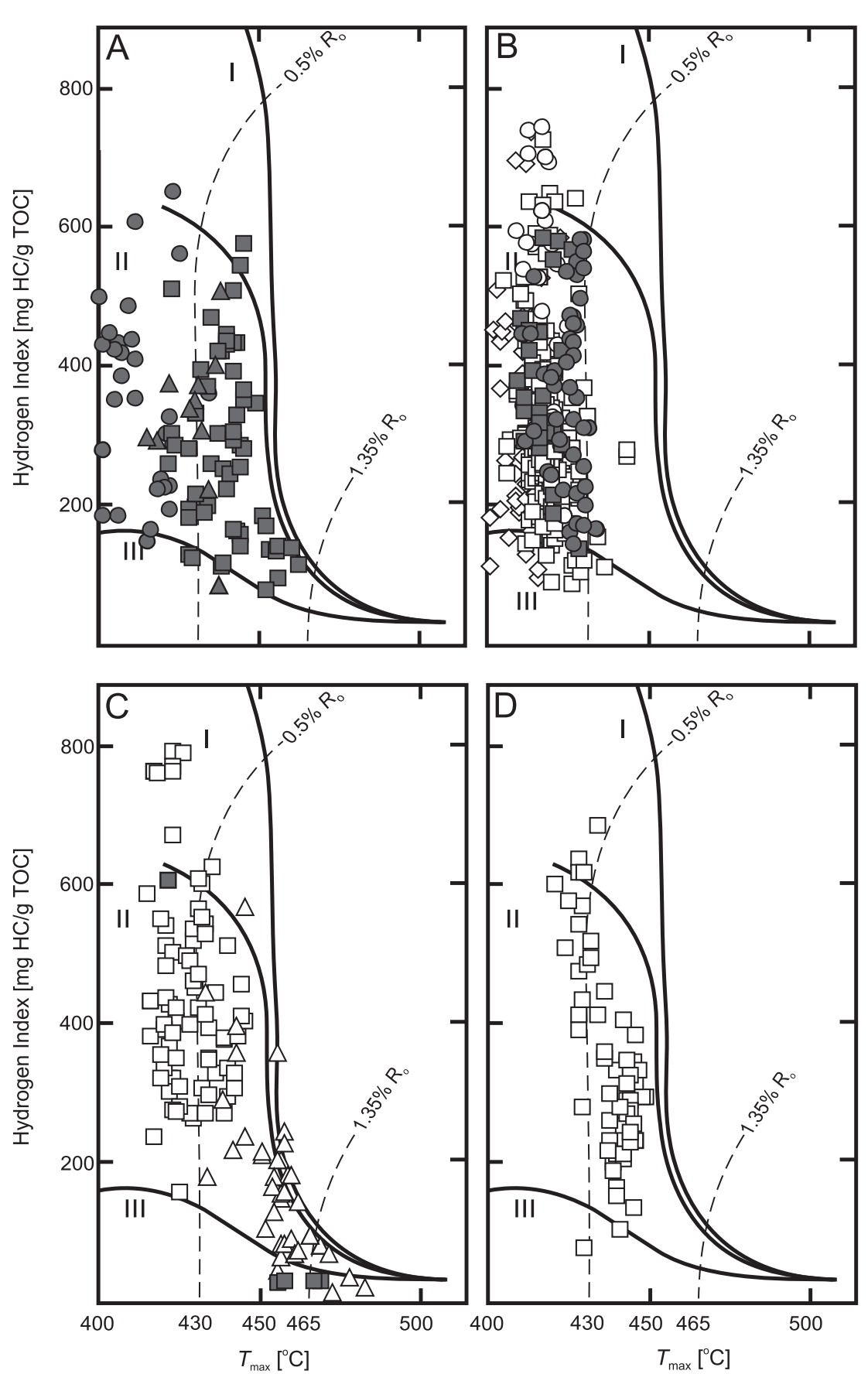

Fig. 4. Rock-Eval hydrogen index versus $T_{\max }$ temperature for recognition of genetic type and maturity of organic matter of the Menilite Shales in (A) Boryslav-Pokuttya, (B) Skole (Skyba), (C) Silesian (Krosno) and (D) Dukla units; maturity paths of kerogen after Espitalie et al. (1985)
Cornford (1994) model for Type II kerogen is ca. $6.0 \mathrm{wt} . \%$. The kinetic parameters of kerogen were determined based on the organic sulphur content in immature samples collected from an exposure at Rudawka Rymanowska. The activation energy for this kerogen is $58.6 \mathrm{kcal} / \mathrm{mol}$ and the pre-exponential factor is $6.06 \times 10^{28} 1 / \mathrm{Ma}$ (Table 4 ).

In the Suche Rzeki-Ustrzyki area the TOC and hydrocarbon contents are similar. The average TOC and hydrocarbon contents amount to $3.9 \mathrm{wt} . \%$ and $18.6 \mathrm{mg} \mathrm{HC} / \mathrm{g}$ rock, respectively (Table 6 and Fig. 3C). The $\mathrm{HI}$ in the Suche Rzeki-Ustrzyki area is low (average $\mathrm{HI}: 313 \mathrm{mg} \mathrm{HC} / \mathrm{g} \mathrm{TOC}$ ), due to high maturity $\left(T_{\max }\right.$ average $442^{\circ} \mathrm{C}$; Table 6 and Fig. 4C).

Oil-prone Type II kerogen dominates, with local admixtures of Type I and Type III kerogens (Fig. 4C). The calculated initial TOC $_{0}$ content is ca. 7.2 wt.\% (Table 3). Taking into account one type of organic matter in the Silesian Unit (Curtis et al., 2004), kinetic parameters of kerogen were determined based on samples collected from the exposure in Monastyets (Table 3 and Fig. 1). The calculated kinetic parameters of kerogen $\left(E_{a}\right.$ and $\left.A_{0}\right)$ are as follows: activation energy $57.6 \mathrm{kcal} / \mathrm{mol}$ and pre-exponential factor $2.93 \times 10^{28} 1 / \mathrm{Ma}$ (Table 4).

In the Borynya-Smozhe area the average TOC content is $4.1 \mathrm{wt}$ \% and the residual hydrocarbon potential is $3.7 \mathrm{mg} \mathrm{HC} / \mathrm{g}$ rock (Table 6$)$. The $\mathrm{HI}$ of those strata is very low (average $10 \mathrm{mg} \mathrm{HC} / \mathrm{g} \mathrm{TOC}$; Fig. 4C). High values of $T_{\text {max }}$ indicate the final stage of low-temperature thermogenic alteration (Table 6 and Fig. 4C). Taking into account the $50 \%$ proportion of Type II and III kerogens present in the organic matter, the initial $\mathrm{TOC}_{0}$ content is ca. $8.0 \mathrm{wt}$ \% (Table 3). Due to the high maturity it is immposible to determine the kinetic type of this organic matter. Immature samples in the Krosno (Silesian) Unit were found at the Jawor exposure (Fig. 1; Kotarba et al., 2007). Elemental analysis of this kerogen indicates the presence of low-sulphur Type II kerogen (Table 2 and Fig. 4). This kerogen is characterized by an activation energy of $59.0 \mathrm{kcal} / \mathrm{mol}$ and a pre-exponential factor of $8.27 \times 10^{28} 1 / \mathrm{Ma}$ (Table 4).

\section{DUKLA UNIT}

ages equal to 23.7 and with averages equal to 23.7 and 18.6, respectively (Table 6$)$.

The $\mathrm{HI}$ of the Menilite Shales is very high (maximum $784 \mathrm{mg} \mathrm{HC/g}$ TOC: at the Monastyrzec exposure; Fig. 4C), with average values of $416 \mathrm{mg} \mathrm{HC} / \mathrm{g}$ TOC in the Sanok and $313 \mathrm{mg}$ $\mathrm{HC} / \mathrm{g} \mathrm{TOC}$ in the Suche Rzeki-Ustrzyki area (Table 6). The mean values are considerably lowered in samples from wells, due to high maturity indicating the initial stage of the "oil window" ( $T_{\max }$ average 435 and $442^{\circ} \mathrm{C}$, respectively; Table 6 and Fig. 4C). Oil-prone Type II kerogen predominates (Fig. 4C). In the Sanok area initial $\mathrm{TOC}_{0}$ content calculated according to the
Although TOC contents varies in a range similar to those of the other units (0.7-11.0 wt.\%), the Menilite Shales of the Dukla Unit reveal the lowest average TOC content (3.5 wt.\%; Table 6 and Fig. 3D; Kosakowski et al., 2009). Similarily, ranges for the hydrocarbon content and $\mathrm{HI}$ are similar, but the mean values are lower than in any other nappe and are $14.4 \mathrm{mg} \mathrm{HC} / \mathrm{g}$ rock and $328 \mathrm{mg} \mathrm{HC} / \mathrm{g} \mathrm{TOC}$, respectively (Table 6 and Figs. 3D, 4D). Oil-prone Type II kerogen occurrs in this unit (Fig. 4D). The temperature $T_{\max }$ values ranges from 422 to $449^{\circ} \mathrm{C}$ (average $439^{\circ} \mathrm{C}$; Table 6 ) show that the organic matter is in the initial and 


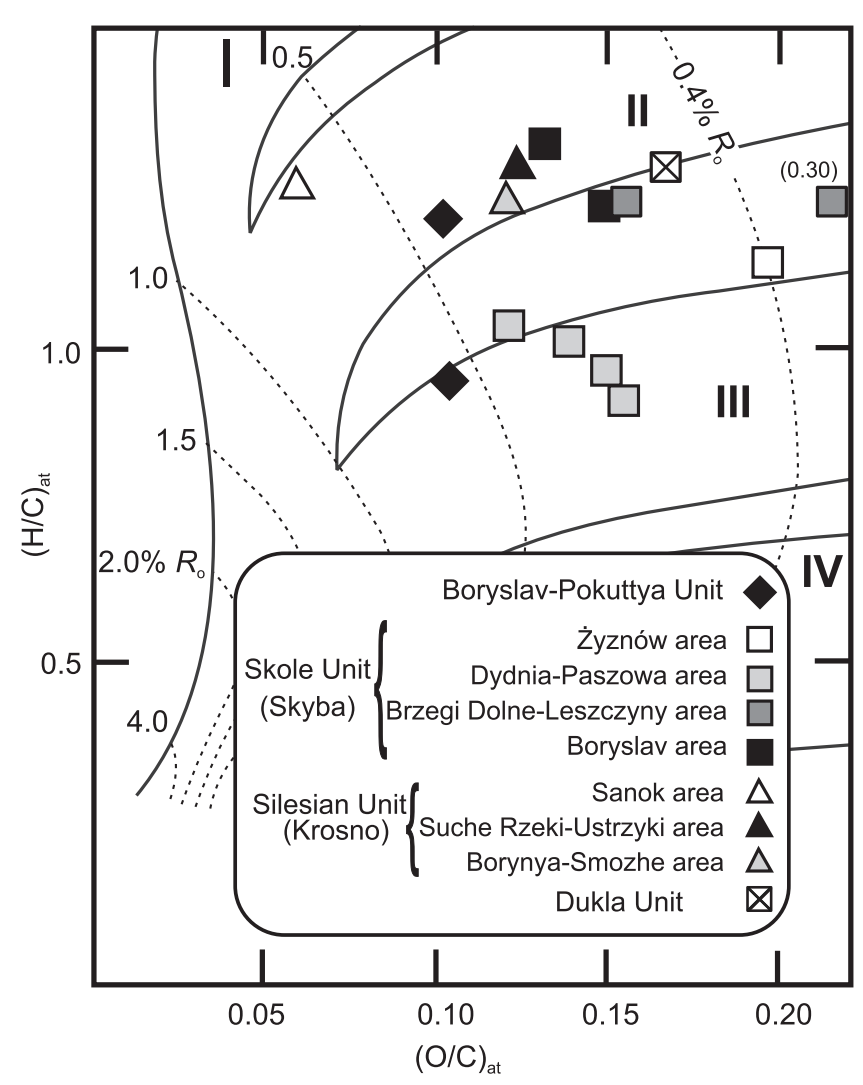

Fig. 5. $(\mathrm{H} / \mathrm{C})_{\text {at }}$ versus $(\mathrm{O} / \mathrm{C})_{\text {at }}$ for recognition of kerogen type in Menilite Shales

Genetic boundaries after Hunt (1996)

main stages of the "oil window" (Fig. 4D). The initial TOC 0 content calculated according to the Cornford (1994) model for Type II kerogen is ca. 5.0 wt.\% (Table 3). Taking into account the Type Il of organic matter, the kinetic parameters of kerogen $\left(E_{a}\right.$ and $\mathrm{A}_{0}$ ) are: activation energy $48.9 \mathrm{kcal} / \mathrm{mol}$, pre-exponential factor $3.87 \times 10^{25} 1 / \mathrm{Ma}$ (Table 4).

\section{BURIAL AND THERMAL HISTORY OF POLISH AND UKRAINIAN CARPATHIANS}

The burial and thermal history of the Outer Carpathians was unique and complicated, as shown by previous studies (Roca et al., 1995; Świerczewska and Tokarski, 1998; Oszczypko, 1999; Zuchiewicz et al., 2002; Jarosiński, 2005; Świerczewska, 2005; Poprawa and Malata, 2006; Malinowski et al., 2008; Kuśmierek, 2010; Sieniawska et al., 2010; Golonka, 2011). It is difficult to establish the time-subsidence history, which is necessary for modelling of the thermal maturity of kerogen and hydrocarbon generation. Only the pre-overthrusting history is relatively simple, as it was mainly controlled by subsidence and was generally similar across the whole Carpathian Basin.

Differences in the burial history, visible in the varied thermal maturity of the kerogen, manifested themselves only at the stage of formation of the Outer Carpathians. The basic burial factors at this stage were related to the thrust-folding processes. Unfortunately, their complexity resulted in the burial history of the flysch successions, and thus the Menilite Shales, being different for each nappe.
BURIAL AND THERMAL HISTORY OF THE BORYSLAV-POKUTTYA UNIT

Modelling of hydrocarbon generation and expulsion in the Boryslav-Pokuttya Unit (Ukrainian Carpathian Foredeep) was performed for three wells: Pivdenny Monastyrets-5, Novoshidnytsia-2, and Pivnichna Zavoda-1 (Fig. 1).

Two overthrust tectonic units, the Skyba and Boryslav-Pokuttya nappes, are visible in the Pivdenny Monastyrets-5 well flysch profile (Fig. 6A). Additionally, a system of internal overthusts can be observed in the Boryslav-Pokuttya Unit, considerably complicating the internal structure of the unit. The Menilite Shales are located in two upper thrust slices at a depth of 4728 to $4858 \mathrm{~m}$ and 4931 to $5060 \mathrm{~m}$, respectively (Fig. 6A).

The tectonic structure is much more complicated in the Novoskhidnytsya-2 well (Figs. 1, 2 and 6B), where four nappes were drilled. The Menilite Shales are located in the top of the Skyba Unit (1648-1760 m), and in the middle and lower thrust slices in the Boryslav-Pokuttya Unit (5223-5245 m and 5475-6020 m; Fig. 6B).

A similarly complicated tectonic structure can be observed in the 5810 m Pivnichna Zavoda-1 well, located in the external part of the Skyba Unit (Fig. 1). The well passes through three nappes, each comprising a flysch succession overlain by Miocene molasse (Koltun et al., 1998). The Menilite Shales occur at the top of the Skyba nappe (821-5810 m) and in three thrust slices in the underlying Boryslav-Pokuttya nappe (3487-3687 m, 4780-4888 m, 5390-5810 m).

The original thickness of the Menilite Shales in the Boryslav-Pokuttya Unit reached slightly more than $1000 \mathrm{~m}$, the overlying molasse deposits are up to $2500 \mathrm{~m}$ thick in areas with a complete succession (Andreyeva-Grigirovich et al., 1986; Vialov et al., 1988; Koltun, 1992; Koltun et al., 1998). The initial deposition of the Menilite Shales in the Boryslav-Pokuttya Unit was assumed, for all modelled wells, to have occurred 35 million of years ago (Fig. 6C, D). The erosion of the Menilite Shales supposedly occurred at $21 \mathrm{Ma}$, the accumulation of Molasse began at $20 \mathrm{Ma}$ and their erosion began at $19 \mathrm{Ma}$ (Kuśmierek, 1994; Koltun, 1998; Kotarba and Koltun, 2005). The magnitude of erosion of the Menilite Shales and the Miocene at this stage of evolution are difficult to determine. When modelling the burial history, average values were assumed for the erosion of the Menilite Shales of $500 \mathrm{~m}$ and for erosion of Miocene strata of 1500 m, respectively (Kuśmierek, 1994; Koltun, 1998; Kotarba and Koltun, 2005). The second assumption accounts for the subsidence processes taking place after the beginning of the overthrusting. The geological evidence suggests that the overthrusting in the Carpathian Foredeep had begun at $18 \mathrm{Ma}$ and the most intense movements, including the main subsidence episode, continued until the late Sarmatian (10 Ma; Koltun et al., 1998). There is, however, insufficient evidence to evaluate specific amounts erosion of the flysch formations. From 10 Ma till the present time some uplift and some remnant thrusting episodes have been inferred (Kuśmierek et al., 2001; Maćkowski et al., 2009), but their magnitude and duration are unknown.

The thermal history of the Outer Carpathians is poorly constrained. Data exist only of temperature measurements in wells and information about present thermal gradients (Koltun, 1992; Kuśmierek and Maćkowski, 1995; Koltun et al., 1998). The model of thermal evolution proposed by the above authors shows an increase in palaeogeothermal gradient values at the pre-thrusting stage and its progressive chilling at the orogenic and post-orogenic stages. A similar change of the thermal field was inferred for the Boryslav-Pokuttya Unit wells. The palaeo- 
Total sulphur and total iron contents, and elemental composition of kerogen from the Menilite Shales

\begin{tabular}{|c|c|c|c|c|c|c|c|c|c|c|c|c|}
\hline \multirow[t]{2}{*}{ Well/Outcrop } & \multirow{2}{*}{$\begin{array}{l}\text { Depth }[m]^{*} \\
\text { Sample No. }\end{array}$} & \multirow{2}{*}{$\begin{array}{l}\mathrm{S}_{\text {total }} \\
\text { [wt.\%] }\end{array}$} & \multirow{2}{*}{$\begin{array}{l}\mathrm{Fe}_{\text {total }} \\
{[\mathrm{wt} . \%]}\end{array}$} & \multicolumn{5}{|c|}{$\begin{array}{c}\text { Elemental composition } \\
{[\text { wt. \%. daf] }}\end{array}$} & \multicolumn{4}{|c|}{ Atomic Ratios } \\
\hline & & & & $\mathrm{C}$ & $\mathrm{H}$ & $\mathrm{O}$ & $\mathrm{N}$ & S & $\mathrm{H} / \mathrm{C}$ & $\mathrm{O} / \mathrm{C}$ & $\mathrm{N} / \mathrm{C}$ & $\mathrm{S} / \mathrm{C}$ \\
\hline \multicolumn{13}{|c|}{ Boryslav-Pokuttya Unit-Pivdenny Monastyrets area } \\
\hline $\begin{array}{l}\text { Pivdenny } \\
\text { Monastyrets-5 }\end{array}$ & 4947.5 & 10.8 & 8.1 & 78.7 & 6.1 & 10.8 & 2.1 & 2.2 & 0.94 & 0.10 & 0.023 & 0.010 \\
\hline \multicolumn{13}{|c|}{ Boryslav-Pokuttya Unit-Novoskhidnytsya-Pivnichna Zavoda area } \\
\hline Nyzhni Popeli 1 & 3363 & 8.9 & 4.9 & 75.7 & 7.6 & 10.0 & 2.5 & 3.9 & 1.20 & 0.10 & 0.029 & 0.020 \\
\hline \multicolumn{13}{|c|}{ Skole Unit-Żyznów area } \\
\hline Żyznów $8^{* \star * *}$ & 1206.6 & 14.7 & 9.9 & 69.6 & 6.4 & 17.8 & 1.8 & 4.4 & 1.11 & 0.19 & 0.023 & 0.023 \\
\hline \multicolumn{13}{|c|}{ Skole Unit-Dydnia-Paszowa area } \\
\hline Krępak** & 59 & 12.6 & 8.82 & 73.8 & 6.4 & 13.9 & 2.6 & 3.3 & 1.04 & 0.14 & 0.030 & 0.017 \\
\hline Rozpucie 1 & 2061 & 16.5 & 13.9 & 77.5 & 6.8 & 12.1 & 2.6 & 0.9 & 1.06 & 0.12 & 0.029 & 0.004 \\
\hline Tyrawa Solna** & 51 & 12.2 & 9.12 & 74.6 & 6.1 & 15.0 & 2.0 & 2.4 & 0.97 & 0.15 & 0.023 & 0.012 \\
\hline Tyrawa Solna & 52 & 10.4 & 4.9 & 70.9 & 5.3 & 15.5 & 1.9 & 6.4 & 0.90 & 0.16 & 0.023 & 0.034 \\
\hline \multicolumn{13}{|c|}{ Skole Unit-Brzegi Dolne-Leszczyny area } \\
\hline Krościenko & 240 & 10.13 & 4.7 & 70.4 & 7.1 & 14.7 & 2.3 & 5.5 & 1.21 & 0.16 & 0.028 & 0.029 \\
\hline Dobromil ${ }^{* * * *}$ & 612 & 9.71 & 0.46 & 59.1 & 5.9 & 23.5 & 1.4 & 10.1 & 1.21 & 0.30 & 0.020 & 0.064 \\
\hline \multicolumn{13}{|c|}{ Skyba Unit-Boryslav area } \\
\hline Boryslav & 1 & 13.9 & 8.5 & 71.4 & 7.3 & 14.0 & 1.9 & 5.5 & 1.23 & 0.15 & 0.022 & 0.029 \\
\hline Verkhe Synevydne & 122 & 5.3 & 1.0 & 72.8 & 7.9 & 12.8 & 1.9 & 4.6 & 1.31 & 0.13 & 0.022 & 0.024 \\
\hline \multicolumn{13}{|c|}{ Silesian Unit-Suche Rzeki-Ustrzyki area } \\
\hline Monasterzec & 252 & 12.21 & 8.8 & 75.5 & 8.7 & 10.8 & 2.3 & 2.7 & 1.38 & 0.11 & 0.026 & 0.013 \\
\hline Monasterzec & 261 & 12.31 & 8.4 & 74.7 & 6.3 & 13.1 & 2.2 & 3.8 & 1.01 & 0.13 & 0.025 & 0.019 \\
\hline \multicolumn{13}{|c|}{ Silesian Unit-Sanok area } \\
\hline $\begin{array}{l}\text { Rudawka } \\
\text { Rymanowska*** }\end{array}$ & $45(2)$ & 15.8 & 12.1 & 80.0 & 8.4 & 6.2 & 2.4 & 3.0 & 1.26 & 0.06 & 0.026 & 0.014 \\
\hline \multicolumn{13}{|c|}{ Krosno Unit-Borynya-Smozhe area } \\
\hline Yavora & 1 & 13.5 & 10.2 & 75.3 & 7.7 & 12.3 & 2.0 & 2.6 & 1.23 & 0.12 & 0.023 & 0.013 \\
\hline \multicolumn{13}{|c|}{ Dukla Unit } \\
\hline Komańcza**** & 348 & 13.67 & 8.12 & 68.8 & 7.4 & 15.3 & 2.5 & 6.1 & 1.28 & 0.17 & 0.031 & 0.033 \\
\hline
\end{tabular}

* - depth for well and sample number for exposure; daf - dry, ash-free basis; ** - data from Curtis et al. (2004); *** - data from Lewan et al. (2006); ${ }^{* * \star *}$ - data from Więclaw et al. (2008)

geothermal gradient in the wells considered was inferred in relation to the present-day average, i.e. $24^{\circ} \mathrm{C} / \mathrm{km}$ (Koltun et al., 1998). This gradient was corrected for individual wells on the basis of the results of downhole temperature measurements. The downhole temperature in the Pivdenny Monastyrets- 5 well was $109^{\circ} \mathrm{C}$ at a depth of $4500 \mathrm{~m}$, and $141^{\circ} \mathrm{C}$ in the Novoskhidnytsya-2 well at a depth of $6000 \mathrm{~m}$ (Y. Koltun, unpubl.). In the Pivnichna Zavoda-1 well the following temperatures were measured: $119^{\circ} \mathrm{C}$ at a depth of $4800 \mathrm{~m}, 132^{\circ} \mathrm{C}$ at $5032 \mathrm{~m}$, and $147^{\circ} \mathrm{C}$ at $5750 \mathrm{~m}$ (Y. Koltun, unpubl.). With the results of these downhole temperature measurements it was possible to correct the present-day geothermal gradient values in the Pivdenny Monastyrets- 5 and Novoskhidnytsya- 2 wells to $22^{\circ} \mathrm{C} / \mathrm{km}$.

On the basis of these geothermal gradient values, their proportional increase to $26-28^{\circ} \mathrm{C} / \mathrm{km}$ was assumed at the sedimentation stage, and a progressive decrease to $24-26^{\circ} \mathrm{C} / \mathrm{km}$ at the thrusting stage and to $18-22^{\circ} \mathrm{C} / \mathrm{km}$ at the post-thrusting stage.

For further analyses of the generation and expulsion of hydrocarbons a model with the best-fit predicted thermal indicator values $\left(T_{\max }\right.$ and $R_{\mathrm{o}}$ ) to downhole measurements was assumed.
BURIAL AND THERMAL HISTORY OF THE SKOLE (SKYBA) UNIT

In the Skole (Skyba) Unit burial and thermal history reconstructions were performed for 6 wells: the Żyznów 8, Rozpucie 1, Brzegi Dolne IG 1 and Leszczyny 1 wells in Poland and the Novoskhidnytsya-2 and Pivnichna Zavoda-1 wells in Ukraine (Figs. 1 and 2).

In these wells the Skole Unit is composed of several folded thrust slices where the flysch succession consists of the Lower Cretaceous Spas Beds to the Oligocene Menilite-Krosno Beds.

The Rozpucie 1 well passed through part of a tectonic fold, where the Menilite Shales occurred at a depth of $1550 \mathrm{~m}$ to continue to the bottom of the well (2321 m deep; Fig. 7A). The Menilite Shales are overlain by the Lower and Middle Krosno Beds. A similarly complicated tectonic structure of the Carpathians can be observed in the Brzegi Dolne IG 1 and Leszczyny 1 wells (Fig. 1). In the Brzegi Dolne IG 1 well the Menilite Shales were penetrated from 0 to $331.5 \mathrm{~m}$ and 2891 to $3193 \mathrm{~m}$ (Fig. 7B). In the Leszczyny 1 well the Menilite Shales were penetrated from 2970 to $3032 \mathrm{~m}$. The wells penetrated a flysch succession representing the Upper Cretaceous-Pale- 
T a b I e 3 of the Menilite Shales in the Skole (Skyba) Unit is very

Mean TOC contents and $\mathrm{HI}$ values in studie areas, and original TOC content (TOC

\begin{tabular}{|l|c|c|c|}
\hline \multicolumn{1}{|c|}{ Tectonic unit/area } & $\begin{array}{c}\mathrm{TOC}_{\text {mean }} \\
{[\mathrm{wt} . \%]}\end{array}$ & $\begin{array}{c}\mathrm{HI}_{\text {mean }} \\
{[\mathrm{mg} \mathrm{HC} / \mathrm{g} \text { TOC] }}\end{array}$ & $\begin{array}{c}\mathrm{TOC}_{0} \\
{[\mathrm{wt} . \%]}\end{array}$ \\
\hline \multicolumn{3}{|c|}{ Boryslav-Pokuttya Unit } \\
\hline Pivdenny Monastyrets & 4.7 & 360 & 4.7 \\
\hline $\begin{array}{l}\text { Novoskhidnytsya-Pivnichna } \\
\text { Zavoda }\end{array}$ & 4.5 & 340 & 5.5 \\
\hline \multicolumn{4}{|c|}{ Skole (Skyba) Unit } \\
\hline Żyznów & 3.3 & 285 & 3.3 \\
\hline Dydnia-Paszowa & 4.2 & 292 & 4.2 \\
\hline \multirow{2}{*}{ Brzegi Dolne-Leszczyny } & 8.7 & 531 & 8.7 \\
\hline Boryslav & 5.0 & 500 & 5.0 \\
\hline \multicolumn{4}{|c|}{ Krosno (Silesian) Unit } \\
\hline Sanok & 3.8 & 360 & 10.4 \\
\hline Suche Rzeki-Ustrzyki & 3.2 & 217 & 7.2 \\
\hline Borynya-Smozhe & 3.9 & 10 & 8.0 \\
\hline \multicolumn{4}{|c|}{ Dukla Unit } \\
\hline & 3.2 & 350 & 5.0 \\
\hline
\end{tabular}

For explanations see Table 1

ogene to Oligocene strata composed of the Inoceramian Beds, Variegated Shales, Hieroglyphic Beds and Krosno Beds. The total depths were $5440 \mathrm{~m}$ in the Brzegi Dolne IG 1 well (Fig. 7B) and $4739.4 \mathrm{~m}$ in the Leszczyny 1 well. The Żyznów 8 well is very shallow, the Menilite Shales occurred there from $550 \mathrm{~m}$ to the total depth of $1210 \mathrm{~m}$.

The modelled wells in the Ukrainian part of the Carpathians are located in the marginal part of the Skyba Unit, at the border with the Boryslav-Pokuttya Unit (Fig. 1). The primary thickness variable. In the Polish part the Menilites reach $550 \mathrm{~m}$ in thickness (Kuśmierek, 1990), and in the Ukrainian part they are $1000 \mathrm{~m}$ thick (Andreyeva-Grigorovich et al., 1986; Vialov et al., 1988). The initial time of deposition of the Menilite Shales in the Skole Unit was assumed to be 33.7-28.0 Ma and the end of deposition 26.4-27.2 Ma, respectively (Fig. 7C, D; Kuśmierek, 1994). In the Skyba Unit the time of deposition was assumed to be the same as for the Menilite Shales in the Boryslav-Pokuttya Unit, e.g., 35-21 Ma (Fig. 6C, D; Koltun et al., 1998; Kotarba and Koltun, 2005). The erosion of the Menilite Shales is estimated at 20.5-21.0 Ma, and the magnitude of erosion of the Menilite Shales and flysch/Miocene cover is assumed to be $500 \mathrm{~m}$ as a maximum in Ukraine. The geological evidence suggests that the overthrusting had begun at $20.5 \mathrm{Ma}$ in the Polish part of the Carpathians and 18 Ma in the Ukrainian part, respectively (Figs. 6C, D and 7C, D; Kuśmierek et al., 1995; Koltun et al., 1998). The most intense movements, and hence the main subsidence episode, continued until 15-10 Ma. As in the Boryslav-Pokuttya Unit, there is not enough evidence to evaluate the specific quantity of eroded parts of some flysch formations. At the post-thrusting stage some uplift and some remnant thrusting episodes are assumed. But there is no constraint on their rate and duration.

The thermal history of the Skole (Skyba) Unit is analogous to that of the Boryslav-Pokuttya Unit (Koltun, 1992; Koltun et al., 1998; Kuśmierek et al., 1995). The thermal evolution model assumed for the Boryslav-Pokuttya Unit wells was applied also in this case. The present-day geothermal gradient in the Skole Unit ranges between 18 and $24^{\circ} \mathrm{C} / \mathrm{km}$ (Kuśmierek et al., 1995; Maćkowski et al., 2009). Owing to the lack of downhole temperature measurements, the present thermal gradients were as-

Ta ble 4

Kinetic parameters of Menilite Shale based on a model considering sulphur contents in kerogen (Lewan and Ruble, 2002)

\begin{tabular}{|l|c|c|c|c|c|}
\hline \multicolumn{1}{|c|}{ Tectonic unit/area } & $\begin{array}{c}\text { Atomic ratio } \\
(\mathrm{S} / \mathrm{C})\end{array}$ & $\begin{array}{c}\text { Mole fraction } \\
\mathrm{S} /(\mathrm{S}+\mathrm{C})\end{array}$ & $\begin{array}{c}\mathrm{E}_{\mathrm{a}} \\
{[\mathrm{kcal} / \mathrm{mol}]}\end{array}$ & $\log \mathrm{A}_{0}$ & $\begin{array}{c}\mathrm{A}_{0} \\
{[1 / \mathrm{Ma}]}\end{array}$ \\
\hline \multicolumn{5}{|c|}{ Boryslav-Pokuttya Unit } \\
\hline Pivdenny Monastyrets-5 & 0.010 & 0.010 & 60.6 & 19.487 & $2.69 \mathrm{E}+29$ \\
\hline Novoskhidnytsya-2 & 0.020 & 0.020 & 55.3 & 17.743 & $4.85 \mathrm{E}+27$ \\
\hline Pivnichna Zavoda-1 & 0.020 & 0.020 & 55.4 & 17.744 & $4.85 \mathrm{E}+27$ \\
\hline \multicolumn{5}{|c|}{ Skole (Skyba) Unit } \\
\hline Żyznów 8 & 0.023 & 0.023 & 53.7 & 17.231 & $1.49 \mathrm{E}+27$ \\
\hline Leszczyny 1 & 0.064 & 0.060 & 34.0 & 10.750 & $4.94 \mathrm{E}+20$ \\
\hline Brzegi Dolne IG 1 & 0.017 & 0.017 & 57.0 & 18.308 & $1.78 \mathrm{E}+28$ \\
\hline Rozpucie 1 & 0.029 & 0.028 & 50.9 & 16.323 & $1.84 \mathrm{E}+26$ \\
\hline Pivnichna Zavoda-1 & 0.026 & 0.025 & 52.6 & 16.879 & $6.63 \mathrm{E}+26$ \\
\hline \multicolumn{7}{|c|}{ Silesian (Krosno) Unit } \\
\hline Rymanów 1 & 0.014 & 0.014 & 58.6 & 18.840 & $6.06 \mathrm{E}+28$ \\
\hline Wetlina 7 & 0.016 & 0.016 & 57.6 & 18.524 & $2.93 \mathrm{E}+28$ \\
\hline Suche Rzeki IG 1 & 0.016 & 0.016 & 57.7 & 18.525 & $2.93 \mathrm{E}+28$ \\
\hline Borynya-2 Dukla Unit & $8.28 \mathrm{E}+28$ \\
\hline \multicolumn{7}{|c|}{0.013} & 59.0 & 18.975 & \\
\hline Jaśliska 2 & 0.013 & 0.032 & 48.9 & 15.645 & $3.87 \mathrm{E}+25$ \\
\hline
\end{tabular}

$E_{a}$ - activation energy, $A_{0}$ - pre-exponential factor 
Rock-Eval characteristics and hydrocarbon potential of the Menilite Shales

\begin{tabular}{|c|c|c|c|c|c|}
\hline Tectonic Unit & \multicolumn{5}{|c|}{ SKOLE (SKYBA) } \\
\hline Area & Żyznów & Dydnia-Paszowa & $\begin{array}{c}\text { Brzegi Dolne- } \\
\text { Leszczyny }\end{array}$ & $\begin{array}{c}\text { Pivdenny } \\
\text { Monastyrets }\end{array}$ & Boryslav \\
\hline $\begin{array}{l}\text { Total organic carbon } \\
\text { TOC [wt.\%] }\end{array}$ & $\frac{0.68 \text { to } 17.2}{7.3} \frac{(72)}{(7)}$ & $\frac{0.21 \text { to } 14.8}{7.3} \frac{(239)}{(10)}$ & $\frac{1.20 \text { to } 13.5}{7.9} \frac{(33)}{(6)}$ & $\frac{1.20 \text { to } 26.2}{6.7} \frac{(46)}{(6)}$ & $\frac{1.81 \text { to } 20.8}{9.0} \frac{(27)}{(4)}$ \\
\hline $\begin{array}{l}T_{\max } \\
{\left[{ }^{\circ} \mathrm{C}\right]} \\
\end{array}$ & $\frac{395 \text { to } 428}{412} \frac{(72)}{(7)}$ & $\frac{406 \text { to } 444}{420} \frac{(239)}{(10)}$ & $\frac{409 \text { to } 444}{418} \frac{(33)}{(6)}$ & $\frac{410 \text { to } 433}{424} \frac{(46)}{(6)}$ & $\frac{409 \text { to } 428}{417} \frac{(27)}{(4)}$ \\
\hline $\begin{array}{l}\mathrm{S}_{2} \\
{[\mathrm{mg} \mathrm{HC} / \mathrm{g} \text { rock] }}\end{array}$ & $\frac{1.15 \text { to } 125.8}{22.5} \frac{(72)}{(7)}$ & $\frac{0.22 \text { to } 77.1}{14.1} \frac{(239)}{(10)}$ & $\frac{3.41 \text { to } 91.8}{41.4} \frac{(33)}{(6)}$ & $\frac{1.90 \text { to } 134.6}{28.3} \frac{(46)}{(6)}$ & $\frac{4.11 \text { to } 77.5}{34.9} \frac{(27)}{(4)}$ \\
\hline $\begin{array}{l}\mathrm{S}_{1}+\mathrm{S}_{2} \\
{[\mathrm{mg} \mathrm{HC/g} \mathrm{rock}]}\end{array}$ & $\frac{1.18 \text { to } 129.7}{23.5} \frac{(72)}{(7)}$ & $\frac{0.27 \text { to } 80.3}{14.6} \frac{(239)}{(10)}$ & $\frac{3.62 \text { to } 94.1}{42.3} \frac{(33)}{(6)}$ & $\frac{2.00 \text { to } 145.7}{29.6} \frac{(46)}{(6)}$ & $\frac{4.71 \text { to } 79.2}{35.8} \frac{(27)}{(4)}$ \\
\hline $\begin{array}{l}\text { Production index } \\
(\mathrm{PI})\end{array}$ & $\frac{0.01 \text { to } 0.15}{0.05} \frac{(72)}{(7)}$ & $\frac{0.01 \text { to } 0.44}{0.05} \frac{(239)}{(10)}$ & $\frac{0.01 \text { to } 0.44}{0.02} \frac{(33)}{(6)}$ & $\frac{0.01 \text { to } 0.08}{0.03} \frac{(46)}{(6)}$ & $\frac{0.02 \text { to } 0.04}{0.03} \frac{(27)}{(4)}$ \\
\hline $\begin{array}{l}\text { Hydrogen index }(\mathrm{HI}) \\
{[\mathrm{mg} \mathrm{HC/g} \mathrm{TOC]}}\end{array}$ & $\frac{94 \text { to } 731}{342} \quad \frac{(72)}{(7)}$ & $\frac{84 \text { to } 718}{297} \quad \frac{(239)}{(10)}$ & $\frac{161 \text { to } 736}{494} \quad \frac{(33)}{(6)}$ & $\frac{159 \text { to } 650}{408} \quad \frac{(46)}{(6)}$ & $\frac{150 \text { to } 654}{408} \quad \frac{(27)}{(4)}$ \\
\hline
\end{tabular}

Explanations as in Table 1

Rock-Eval characteristics and hydrocarbon potential of the Menilite Shales

\begin{tabular}{|c|c|c|c|c|}
\hline Tectonic Unit & \multicolumn{3}{|c|}{ SILESIAN (KROSNO) } & \multirow[b]{2}{*}{ DUKLA } \\
\hline Area & Sanok & $\begin{array}{c}\text { Suche Rzeki } \\
\text {-Ustrzyki }\end{array}$ & $\begin{array}{l}\text { Borynya - } \\
\text { Smozhe }\end{array}$ & \\
\hline $\begin{array}{l}\text { Total organic carbon } \\
\text { TOC [wt.\%] }\end{array}$ & $\frac{1.36 \text { to } 17.3}{4.7} \frac{(38)}{(3)}$ & $\frac{0.42 \text { to } 20.2}{3.9} \frac{(100)}{(12)}$ & $\frac{1.90 \text { to } 7.81}{4.1} \frac{(15)}{(3)}$ & $\frac{0.67 \text { to } 11.0}{3.5} \frac{(15)}{(3)}$ \\
\hline $\begin{array}{l}T_{\max } \\
{\left[{ }^{\circ} \mathrm{C}\right]}\end{array}$ & $\frac{427 \text { to } 445}{435} \frac{(38)}{(3)}$ & $\frac{416 \text { to } 593}{442} \frac{(100)}{(12)}$ & $\frac{422 \text { to } 589}{530} \frac{(15)}{(3)}$ & $\frac{422 \text { to } 449}{439} \frac{(15)}{(3)}$ \\
\hline $\begin{array}{l}\mathrm{S}_{2} \\
{[\mathrm{mg} \mathrm{HC} / \mathrm{g} \mathrm{rock}]}\end{array}$ & $\frac{3.61 \text { to } 103.7}{22.3} \frac{(38)}{(3)}$ & $\frac{0.18 \text { to } 158.5}{17.8} \frac{(100)}{(12)}$ & $\frac{0.15 \text { to } 46.7}{3.7} \frac{(15)}{(3)}$ & $\frac{0.52 \text { to } 63.4}{13.4} \frac{(15)}{(3)}$ \\
\hline $\begin{array}{l}\mathrm{S}_{1}+\mathrm{S}_{2} \\
{[\mathrm{mg} \mathrm{HC} / \mathrm{g} \text { rock] }}\end{array}$ & $\frac{4.01 \text { to } 106.9}{23.7} \frac{(38)}{(3)}$ & $\frac{0.30 \text { to } 167.5}{18.6} \frac{(100)}{(12)}$ & $\frac{0.19 \text { to } 47.9}{3.8} \frac{(15)}{(3)}$ & $\frac{0.21 \text { to } 68.8}{14.4} \frac{(15)}{(3)}$ \\
\hline $\begin{array}{l}\text { Production index } \\
(\mathrm{PI})\end{array}$ & $\frac{0.04 \text { to } 0.67}{0.27} \frac{(38)}{(3)}$ & $\frac{0.02 \text { to } 0.45}{0.09} \frac{(100)}{(12)}$ & $\frac{0.03 \text { to } 0.43}{0.20} \frac{(15)}{(3)}$ & $\frac{0.02 \text { to } 0.42}{0.08} \frac{(15)}{(3)}$ \\
\hline $\begin{array}{l}\text { Hydrogen index }(\mathrm{HI}) \\
{[\mathrm{mg} \mathrm{HC} / \mathrm{g} \text { TOC] }}\end{array}$ & $\frac{153 \text { to } 617}{416} \quad \frac{(38)}{(3)}$ & $\frac{15 \text { to } 784}{313} \quad \frac{(100)}{(12)}$ & $\frac{5 \text { to } 599}{54} \quad \frac{(15)}{(3)}$ & $\frac{78 \text { to } 681}{328} \quad \frac{(15)}{(3)}$ \\
\hline
\end{tabular}

Explanations as in Table 1

sumed to be $23^{\circ} \mathrm{C} / \mathrm{km}$ for both the wells analysed in the Polish part of the Carpathians.

Based on the geothermal gradient values, their proportional increase to $33-25^{\circ} \mathrm{C} / \mathrm{km}$ was assumed at the sedimentation stage, with progressive decrease to $30-24^{\circ} \mathrm{C} / \mathrm{km}$ at the thrusting stage and $21-24^{\circ} \mathrm{C} / \mathrm{km}$ at the post-thrusting stage.

\section{BURIAL AND THERMAL HISTORY OF SILESIAN (KROSNO) UNIT}

In the Silesian (Krosno) Unit burial and thermal history reconstructions were performed in four wells: Rymanów 1, Wetlina 7, Suche Rzeki IG 1, and Borynya-2 (Fig. 1).

The Wetlina 7 well passed through part of a tectonic fold, where the Menilite Shales occurred at a depth interval of 1735 to $2797 \mathrm{~m}$ (Fig. 8A, C). The Menilite Shales are overlain with the Transition Beds. A more complicated Carpathian tectonic structure can be observed in the Suche Rzeki IG 1 and Rymanów 1 wells. In the Suche Dolne IG 1 well the Menilite Shales occur in the lowermost part, at a depth of 3150 to
$3502 \mathrm{~m}$. In the Rymanów 1 well the Menilite Shales occur in the middle fold, at a depth of 2495 to $3152 \mathrm{~m}$ and 3317 to $3670 \mathrm{~m}$.

In the Krosno nappe, the source rocks appear in the Lower Holovets'ko Formation, equivalent to the Menilite Shales and Transition formations in the Skyba and Boryslav-Pokuttya units. The geological profile of the Borynya-2 well is very complicated (Fig. 1). This formation occurs at the depths of 10-230 m, 2650-3102, and 4430-5230 m (Fig. 8B).

The results of Rock Eval $T_{\max }$ show a much more advanced thermal maturity of kerogen in the Menilite Shales (Fig. 8C, D). The results indicate a deeper depth of burial and/or higher palaeothermal gradients.

In the Suche Rzeki IG 1 well the present-day geothermal gradient was calculated using a temperature of $85.2^{\circ} \mathrm{C}$ at $2955 \mathrm{~m}$ depth, that is $85.2^{\circ} \mathrm{C}$. In the Borynya- 2 well the present-day geothermal gradient was calculated using the results of downhole temperature values measured for the following depths: $4073 \mathrm{~m}-112^{\circ} \mathrm{C}, 4647 \mathrm{~m}-131^{\circ} \mathrm{C}$, and $4805 \mathrm{~m}-$ $132^{\circ} \mathrm{C}$, respectively. With the results of downhole temperatures it was possible to assess the values of the present-day geothermal gradient in the Suche Rzeki IG 1 well and Borynya-2 well to 

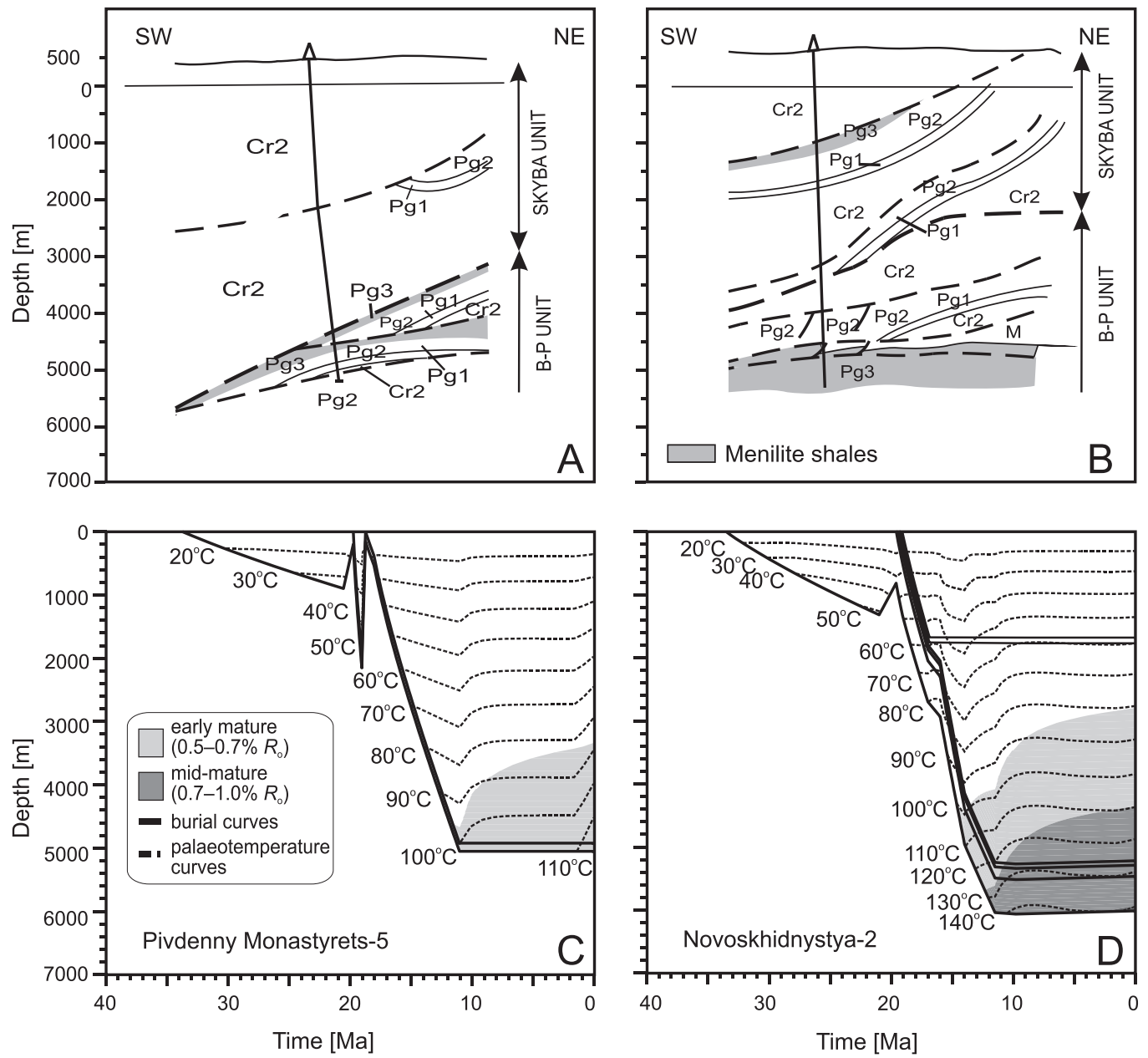

Fig. 6. Geological profile and burial history with thermal evolution of the Menilite Shales in (A and C) Pivdenny Monastyrets-5 and (B and D) Novoskhidnytsya-2 wells in the Boryslav-Pokuttya Unit

$\mathrm{Cr}_{2}$ - Upper Cretaceous, Pg - Paleogene, M - Miocene, B-P Unit - Boryslav-Pokuttya Unit

be $26^{\circ} \mathrm{C} / \mathrm{km}$. Due to the lack of downhole temperature measurements, the present thermal gradients were assumed at a level of $26^{\circ} \mathrm{C} / \mathrm{km}$ for the Rymanów 1 and Wetlina 7 wells.

Based on the above geothermal gradient values, their proportional increase to $30-52^{\circ} \mathrm{C} / \mathrm{km}$ at the sedimentation stage was inferred, and it progressively decreased to $41-25^{\circ} \mathrm{C} / \mathrm{km}$ at the thrusting stage and to $36-25^{\circ} \mathrm{C} / \mathrm{km}$ at the post-thrusting stage.

\section{BURIAL AND THERMAL HISTORY OF THE DUKLA UNIT}

Modelling of hydrocarbon generation and expulsion in the Dukla Unit was performed for the Jaśliska 2 well (Fig. 1).

The Menilite Shales occur in two upper thrust slices (1755-2286 m, and 2709-2769 m; Fig. 9A).

The results of Rock Eval $T_{\max }$ from the Komańcza and Maniów exposures used for calibration of thermal maturity show different maturities, from the early to the main phases of the "oil window" (Fig. 9B). The results unequivocally indicate the varied burial history of the Menilite Shales in the Dukla Unit. For reconstruction of the burial history in the Jaśliska 2 well, Rock Eval data from the Komańcza exposure were used.

Because of the lack of downhole temperature measurements, the present thermal gradients were inferred at a level of $25^{\circ} \mathrm{C} / \mathrm{km}$ for the well analysed. Based on the above geothermal gradient values, their proportional increase to $25.5^{\circ} \mathrm{C} / \mathrm{km}$ at the sedimentation stage was inferred, with progressive increase to $29.5^{\circ} \mathrm{C} / \mathrm{km}$ at the thrusting stage and $25^{\circ} \mathrm{C} / \mathrm{km}$ at post-thrusting stage.

\section{MODELLING OF GENERATION AND EXPULSION OF HYDROCARBONS}

\section{BORYSLAV-POKUTTYA UNIT}

The thickness of the Menilite Shales in the Boryslav-Pokuttya Unit in the wells analysed varies from $22 \mathrm{~m}$ to $420 \mathrm{~m}$. These rocks have a very good to excellent hydrocarbon 

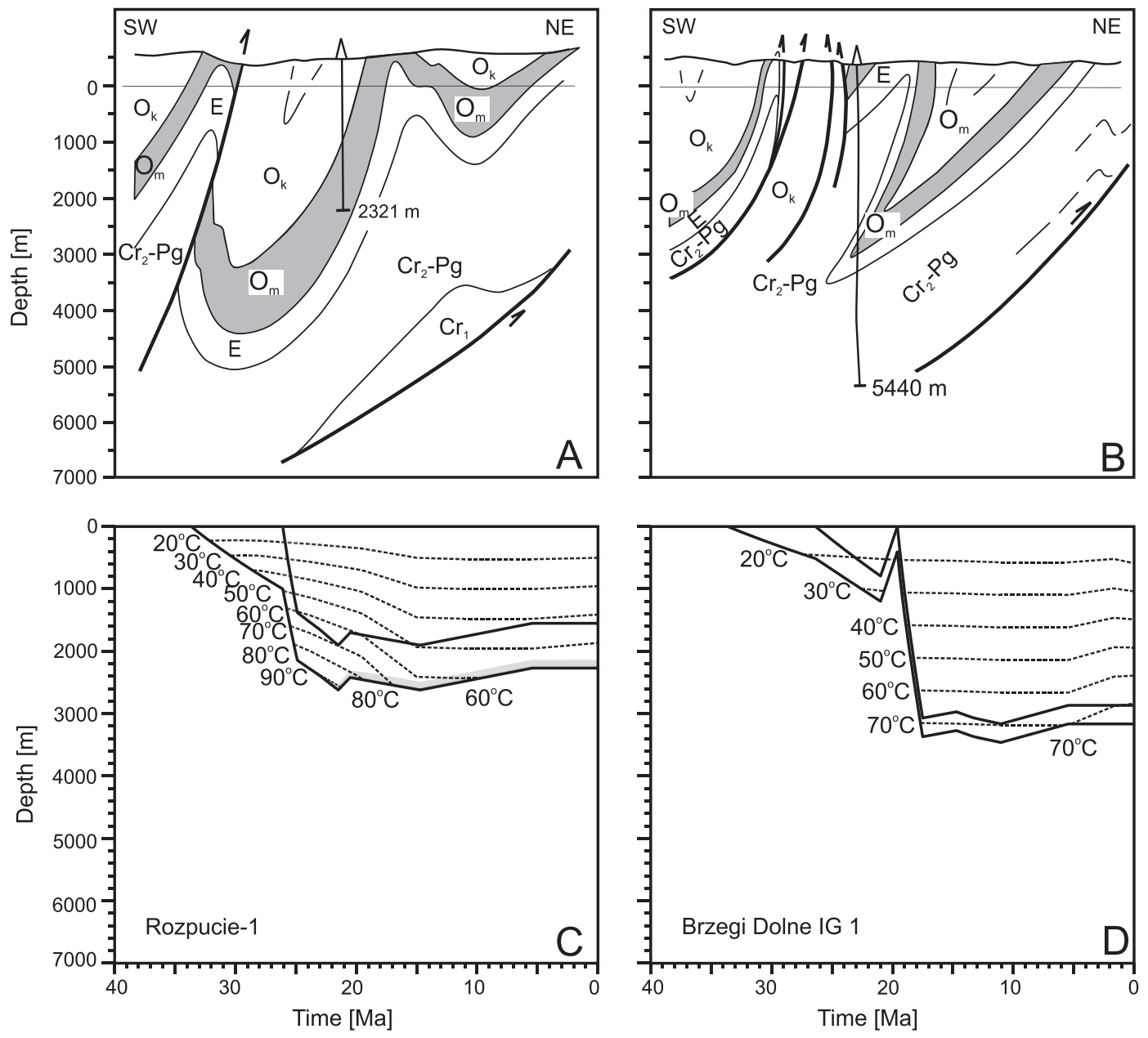

Fig. 7. Geological profile and burial history with thermal evolution of the Menilite Shales in (A and C) Rozpucie 1 and (B and D) Brzegi Dolne IG 1 wells in the Skole (Skyba) Unit

$\mathrm{Cr}_{1}$ - Lower Cretaceous, E - Eocene, $\mathrm{O}_{\mathrm{m}}$ - Oligocene (Menilite Shales), $\mathrm{O}_{\mathrm{k}}$ - Oligocene (Krosno Beds); for other explanations see Figure 6

potential. They have maturity of about 0.5 to $1.1 \%$ vitrinite reflectance (Fig. 10A).

The model showed that a temperature exceeding $100^{\circ} \mathrm{C}$ was achieved at 16-12 Ma at levels deeper than $4000 \mathrm{~m}$ (Fig. $6 \mathrm{C}, \mathrm{D})$. This temperature corresponds to the onset of hydrocarbon generation (the early "oil window"). The maximum temperatures of $120-140^{\circ} \mathrm{C}$ were reached at the post-thrusting stage (Fig. 6D). The history of hydrocarbon generation and expulsion was analysed by means of computer modelling with an assumed $10 \%$ saturation level and individual kinetic parameters. The main controls on maturity, transformation of organic matter and hydrocarbon generation in the study area were rapid subsidence, and thrusting and folding of the nappes (Figs. 5 and 9A). The maturity level reached up to $1.1 \% R_{\mathrm{o}}$ and the transformation ratio reached up to $40 \%$ (Fig. 11A).

Hydrocarbon generation within the Menilite Shales source rocks in the wells modelled commenced at the beginning of overthrusting of the nappes. Oil and gas expulsion started at the post-thrusting stage in the Novoskhidnytsya-2 and Pivnichna Zavoda-1 wells. In the Pivdenny Monastyrets-5 well expulsion has not been initiated (Fig. 12A). For the above maturity model, the calculated amount of generation potential for the Menilite Shales reaches $135 \mathrm{mg} \mathrm{HC/g}$ TOC in the Novoskhidnytsya-2 well and $110 \mathrm{mg} \mathrm{HC} / \mathrm{g}$ TOC in the Pivnichna Zavoda-1 well (Fig.
12). The expelled oil and gas represented $60 \%$ in the Novoskhidnytsya-2 well and $80 \%$ in the Pivnichna Zavoda-1 well.

\section{SKOLE (SKYBA) UNIT}

The TOC content and hydrocarbon potential of the Menilite Shales in the Skole (Skyba) Unit is high, but maturity and transformation of kerogen are insufficient to start generation of hydrocarbons (Fig. 11A). The maturity of kerogen in the Rozpucie 1 well is a little higher than $0.5 \% R_{o}$ but kinetics of transformation of kerogen is insufficient for generation (Figs. 9A and 10A). The opposite situation can be observed in the Leszczyny 1 well, where maturity is below $0.5 \% R_{0}$, but the kinetic reactions allow for generation of hydrocarbons (Figs. 9A and 10A).

\section{SILESIAN (KROSNO) UNIT}

The Menilite source rocks in the Silesian (Krosno) Unit also have a very good to excellent hydrocarbon potential, but they have a higher maturity level of about $1.3-1.5 \% R_{0}$. Their thickness varies from 352 to $1062 \mathrm{~m}$. The history of hydrocarbon generation and expulsion was modelled in the Rymanów 1, 

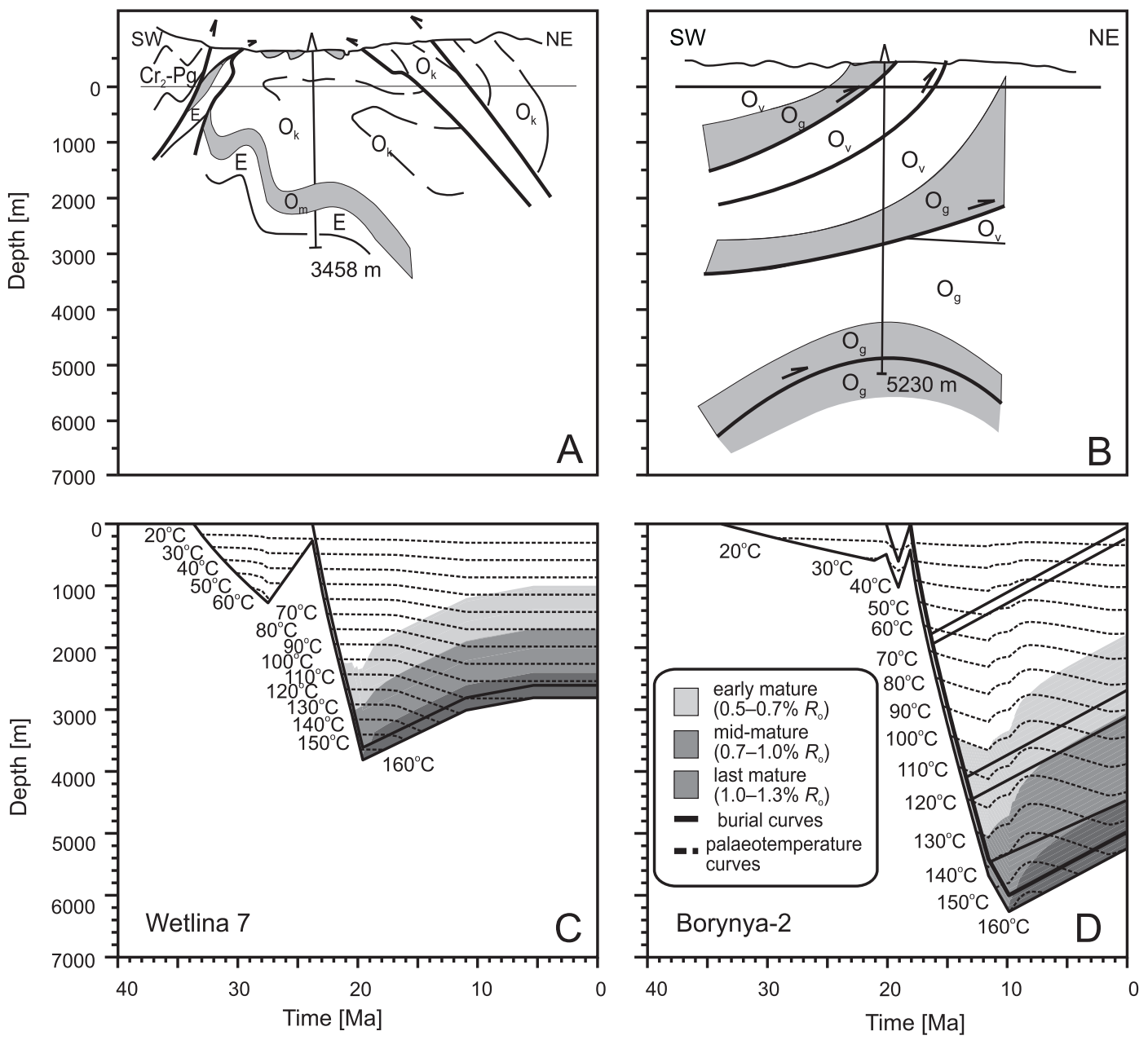

Fig. 8. Geological profile and burial history with thermal evolution of the Menilite Shales in (A and C) Wetlina 7 and (B and D) Borynya-2 wells in the Silesian (Krosno) Unit

$\mathrm{O}_{g}$ - Oligocene (Holovets'ko Beds), $\mathrm{O}_{v}$ - Oligocene (Verkhovyna Beds); for other explanations see Figure 6
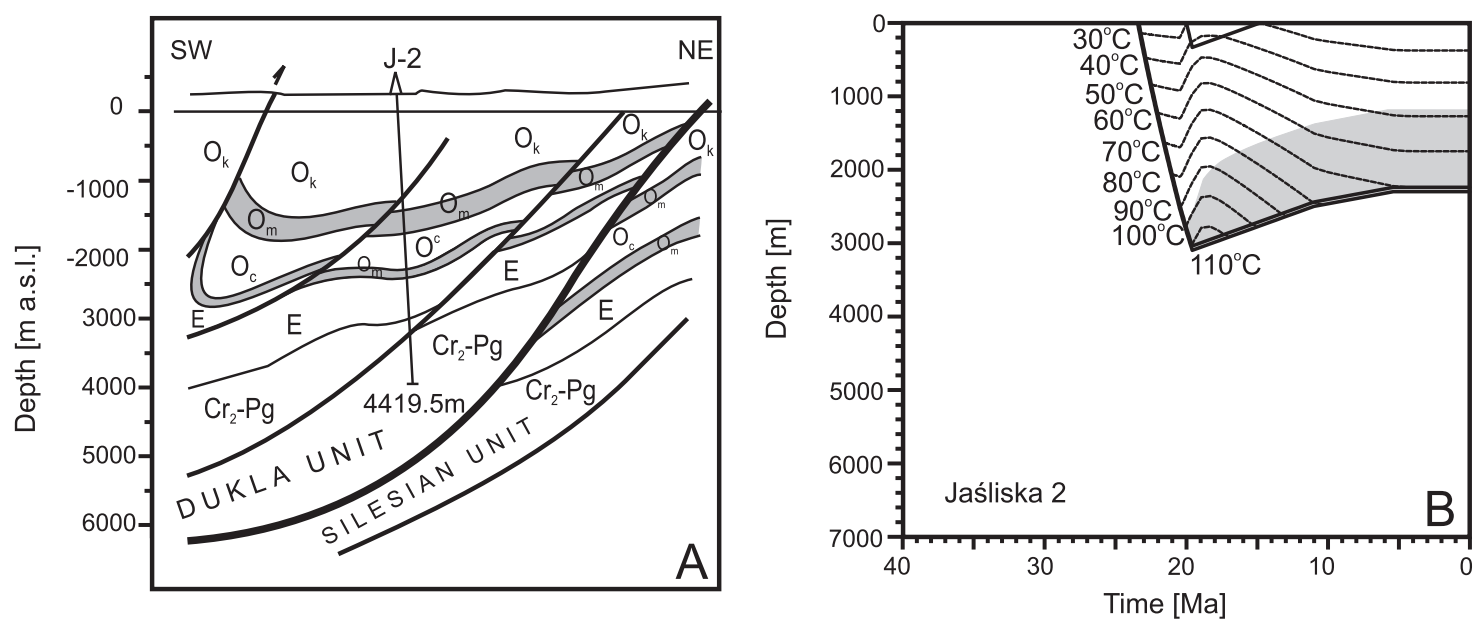

Fig. 9. Geological profile and burial history with thermal evolution of the Menilite Shales in Jaśliska 2 well in the Dukla Unit 


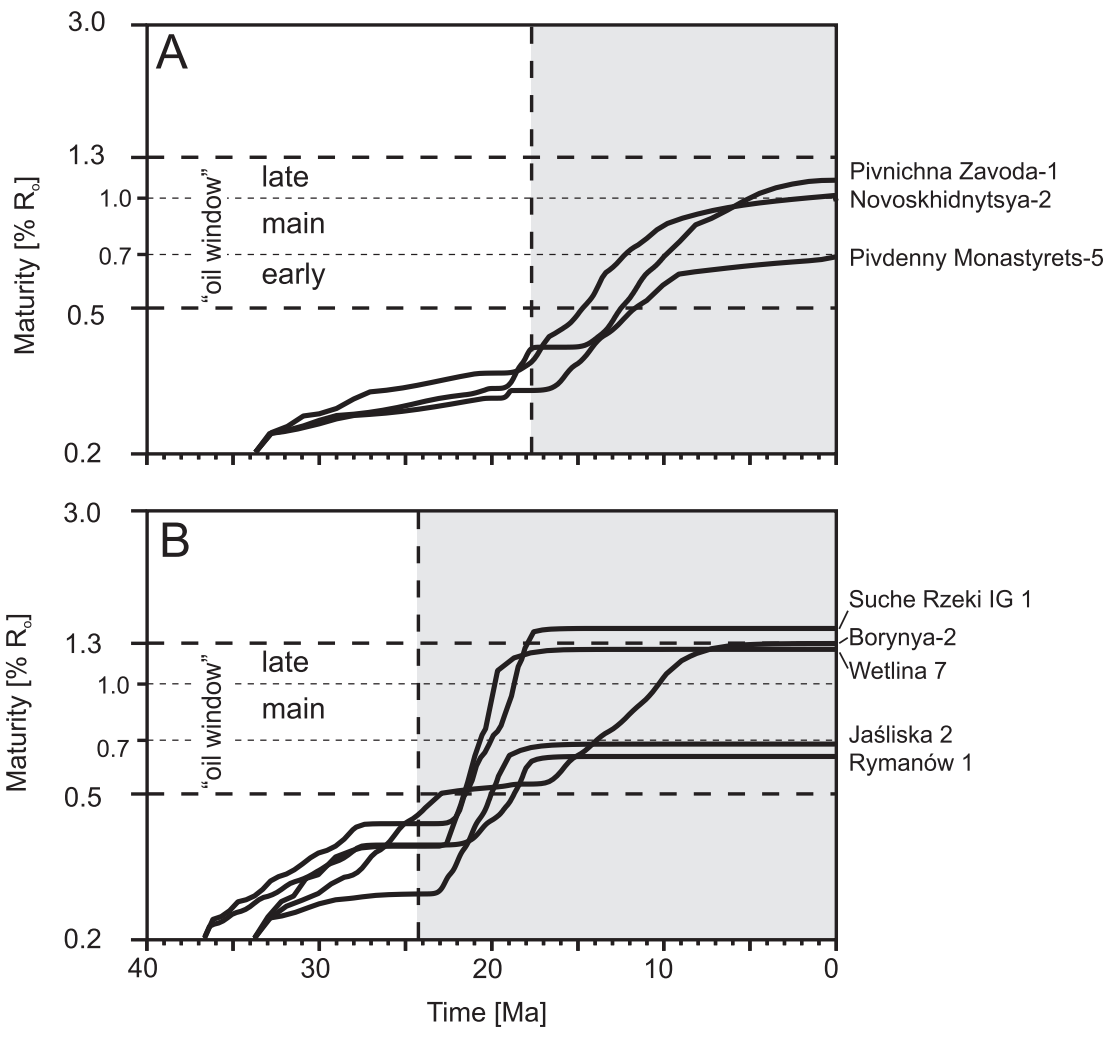

Fig. 10. Evolution of maturity of Menilite source rocks in modelled wells
Wetlina 7, Suche Rzeki IG 1 and Borynya-2 wells (Fig. 1). The onset of hydrocarbon generation (the early "oil window") was achieved at 23-21 Ma in the Polish part of the Silesian Nappe, and 16 $\mathrm{Ma}$ in the Ukrainian part (Fig. 10B). Maximum temperatures of $160^{\circ} \mathrm{C}$ were reached at the end of the thrusting stage (Fig. 8C, D). The history of hydrocarbon generation and expulsion was analysed by means of computer modelling with an assumed $10 \%$ saturation level and individual kinetic parameters. The transformation ratio reached $50 \%$ in the Rymanów 1 well and $80 \%$ in the Wetlina 7 well (Fig. 11B). Kerogen in the Suche Rzeki IG 1 well has been completely transformed (Fig. 11B). In the Borynya-2 well the hydrocarbon generation within the Menilite source rocks commenced at the initial stage of overthrusting of nappes (Fig. 11B). For the above transformation ratios, the calculated amount of generation potential for the Menilite Shales reached $500 \mathrm{mg} \mathrm{HC} / \mathrm{g}$ TOC in the Suche Rzeki IG 1 well, $390 \mathrm{mg}$ $\mathrm{HC} / \mathrm{g} \mathrm{TOC}$ in the Wetlina 7 well, $250 \mathrm{mg}$ $\mathrm{HC} / \mathrm{g}$ TOC in the Rymanów 1 well and 225 $\mathrm{mg} \mathrm{HC} / \mathrm{g}$ TOC in the Borynya-2 well (Fig. 13). The expelled oil and gas there represented up to $95 \%$.
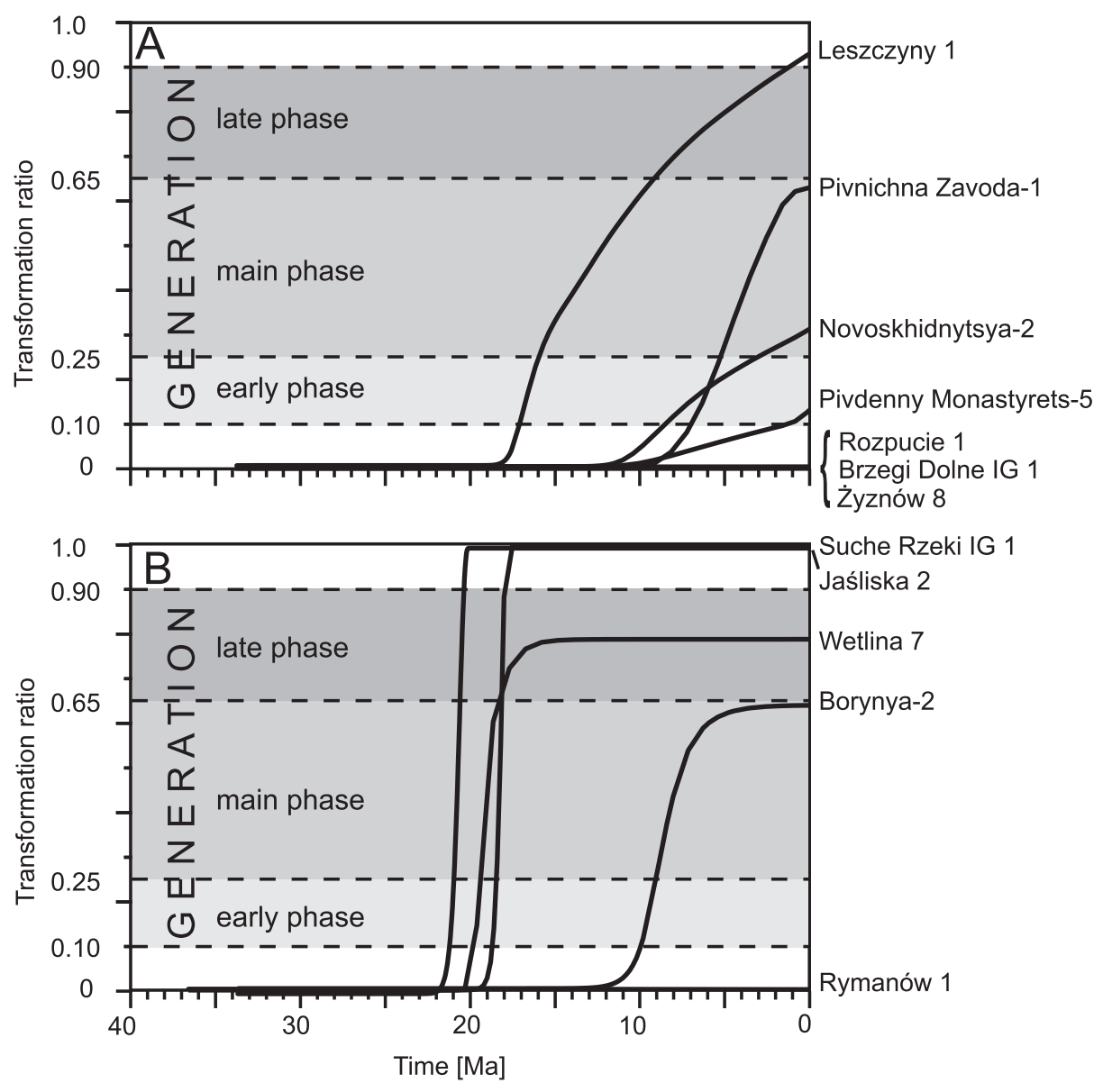

Fig. 11. Transformation of kerogen in Menilite source rocks 


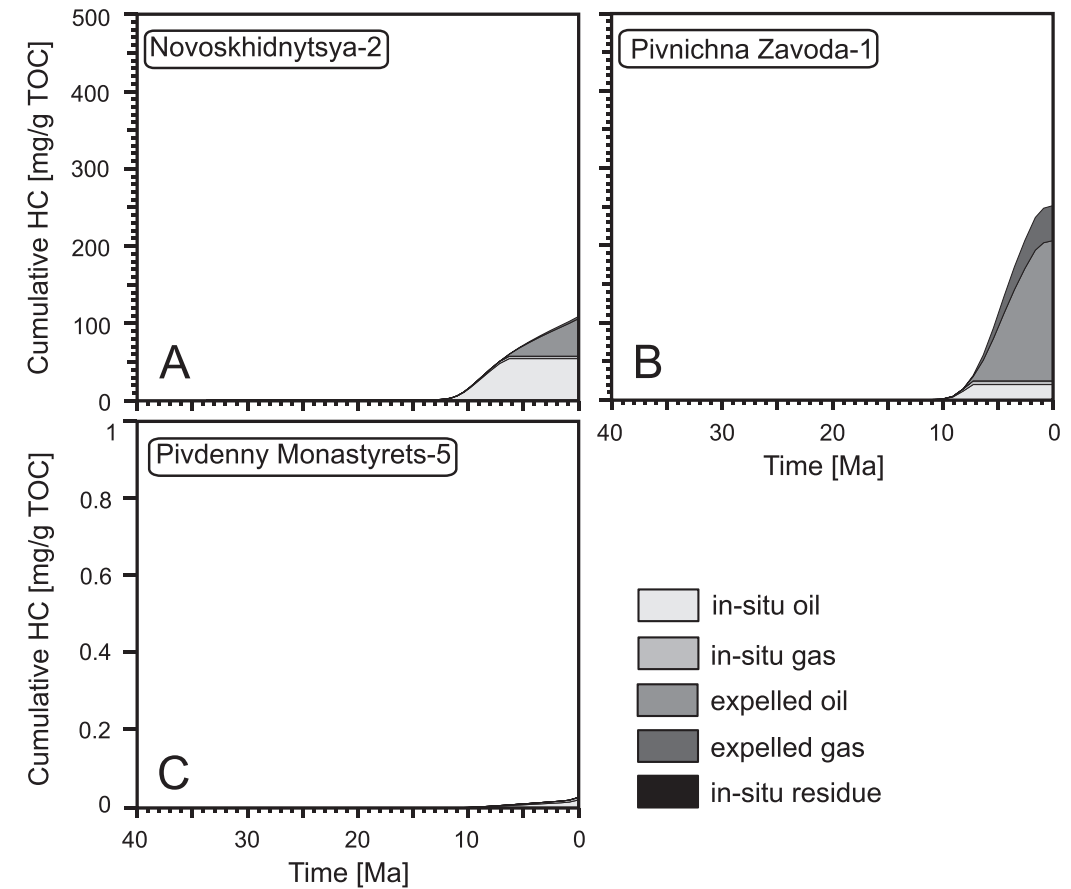

Fig. 12. Cumulative amount of generated hydrocarbons from organic matter of Menilite Shales in the Boryslav-Pokuttya Unit in (A) Pivdenny Monastyrets-5, (B) Novoskhidnytsia-2 and (C) Pivnichna Zavoda-1 wells
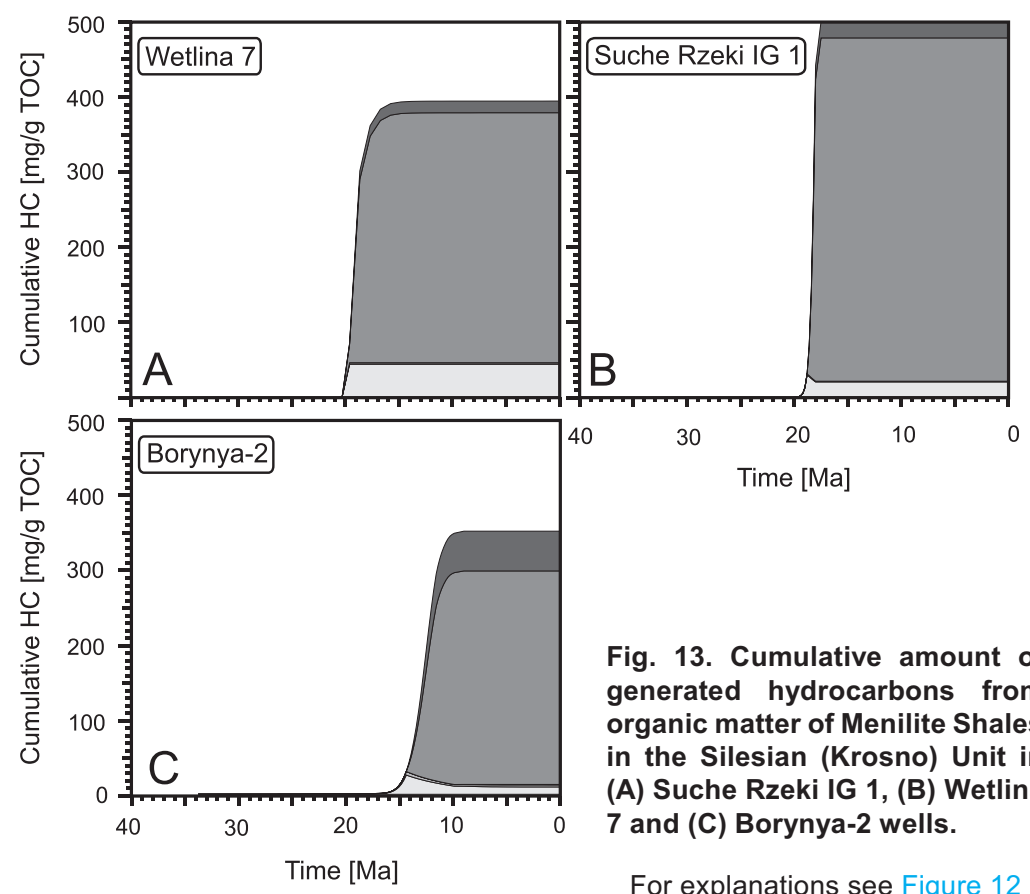

Fig. 13. Cumulative amount of generated hydrocarbons from organic matter of Menilite Shales in the Silesian (Krosno) Unit in (A) Suche Rzeki IG 1, (B) Wetlina 7 and (C) Borynya-2 wells.

For explanations see Figure 12 bons. They contain mainly oil-prone, Type II organic matter. As in the other units, the major control on maturity and transformation of organic matter was rapid subsidence, and thrusting and folding of the nappes (Figs. 8B and 9B). The maturity level reached up to $0.7 \% R_{\mathrm{o}}$ and kerogen was totally transformed to hydrocarbons (Fig. 11B). The model showed that the onset of hydrocarbon generation (the early "oil window") was achieved at $21 \mathrm{Ma}$, at about $2000 \mathrm{~m}$ burial depth and at a temperature of $80^{\circ} \mathrm{C}$. The main and late generation (25-90\% of transformation of kerogen), were reached at $1 \mathrm{Ma}$ at the $2200-2600 \mathrm{~m}$ burial depth at temperatures below $100^{\circ} \mathrm{C}$. Oil and gas expulsion started at the end of the thrusting stage and developed at the post-thrusting stage. For the above transformation the calculated amount of generation potential for the source rocks reaches about $550 \mathrm{mg} \mathrm{HC} / \mathrm{g}$ TOC. The expelled oil and gas there represented $75 \%$.

\section{CONCLUSIONS}

1D modelling of hydrocarbon generation and expulsion processes for the Menilite Shales source rocks was performed in four tectonic units of the Polish and Ukrainian parts of the Outer Carpathians: the Boryslav-Pokuttya, Skole (Skyba), Silesian (Krosno) and Dukla units. Results of the modelling reveal that at the sedimentary stage, before tectonic rebuilding of the basin, the Menilite Shales did not reach a level of thermal maturity high enough to generate hydrocarbons. The burial history at the thrusting stage differentiated the thermal maturity of kerogen, thus differentiating the process of generation and expulsion of hydrocarbons in the Menilite Shales within all the above mentioned units.

Hydrocarbon generation within source rocks in the Boryslav-Pokuttya Unit was initiated at the preliminary stage of the Outer Carpathian units overthrusting, at a depth exceeding $4 \mathrm{~km}$. Such a depth had been reached between $15 \mathrm{Ma}$ in the Pivnichna Zavoda area and $10 \mathrm{Ma}$ in the Pivdenny Monastyrets area. Depending on the depth of burial of the Menilite Shales, the kerogen transformation level is from about 10 to over $80 \%$. The quantity of generated hydrocarbons may even reach $135 \mathrm{mg} \mathrm{HC} / \mathrm{g}$ TOC.

Generally, the Menilite Shales in the Skole (Skyba) Unit were not sufficiently mature to initiate hydrocarbon generation processes.

The Menilite Shales in the Krosno and Dukla units have the highest degree of thermal transformation. The initial conditions of hydrocarbon generation were obtained in the Polish part at some $21 \mathrm{Ma}$, at a depth exceeding $2 \mathrm{~km}$. In the Ukrainian part of this unit, the beginning of hydrocarbon generation are $491 \mathrm{~m}$ in the first fold and $60 \mathrm{~m}$ in the second one (Fig. 9A). The Menilite Shales show very good hydrocarbon potential. They have maturity of about $0.4-1.0 \% R_{0}$. Jarmołowicz-Szulc et al. (2012) provide evidence of even higher maturity of organic matter, which indicates greater ability to generate hydrocar- 
dates back to about $16 \mathrm{Ma}$, at a depth of about $4 \mathrm{~km}$. Depending on the depth of burial of the Menilite Shales, the degree of kerogen transformation was from about $20 \%$ in the Borynya-2 well to complete transformation in the Suche Rzeki IG 1 well. The quantity of hydrocarbons generated was as much as $550 \mathrm{mg} \mathrm{HC} / \mathrm{g}$ TOC.

The analysis of hydrocarbon generation and expulsion from the source rocks of all the units reveals that the highest maturity and the highest potential were obtained by the Menilite Shales from the Silesian and Dukla units. This is the place where the earliest generation processes started, and where the level of kerogen transformation and the expulsion potential were highest.

Acknowledgments. Financial support of this work come from the statutory fund of the AGH University of Science and
Technology (project number 11.11.140.293) and the Polish Ministry of Science and Higher Education Grant No. 4 T12B 02427 (AGH-UST project no. 18.25.140.203). Dr. A. Kowalski and Mr. H. Zych helped with the analytical work, Dr. D. Więcław calculated the kinetic parameters of kerogen, Dr. M. Wróbel assisted in numerical modelling and preparation of figures, Dr. Y. Koltun (National Academy of Sciences of Ukraine, Lviv) and Prof. J. Kuśmierek prepared geological cross-sections for the Ukrainian and Polish part of the Carpathians; their help is gratefully acknowledged. Special thanks go to Prof. M.J. Kotarba and Prof. T.M. Peryt for constructive and critical discussion, and language review of the manuscript. Dr. Y. Koltun and two anonymous reviewers are thanked for their critical comments and suggestions for manuscript improvement.

\section{REFERENCES}

Andreyeva-Grigorovich A.S., Gruzman A.D., Reifman L.M., Smirnov S.E. (1986) Biostratigraphical characteristics of the type sequence of the Menilite shales on Chechva River (Ukrainian Carpathians) (in Russian). Paleontologicheskiy Zhurnal, 23: 83-89.

Baskin D.K. (1997) Atomic H/C ratio of kerogens as an estimate of thermal maturity and organic matter conversion. AAPG Bulletin, 81: 1437-1450.

Bessereau G., Roure F., Kotarba M., Kuśmierek J., Strzetelski W. (1996) Structure and hydrocarbon habitat of the Polish Carpathians. Memoires du Museum National d'Histoire Naturelle, 170: 343-373.

Bieńkowska M. (2004) Taphonomy of ichthyofauna from an Oligocene sequence (Tylawa Limestones horizon) of the Outer Carpathians, Poland. Geological Quarterly, 48 (2): 181-192.

Burnham A.K., Braun R.L., Samoun A.M. (1987) Comparison of methods for measuring kerogen pyrolysis rates and fitting kinetic parameters. Energy and Fuels, 1: 452-458.

Cornford C. (1994) Mandal-Ekofisk(!) Petroleum System in the Central Graben of the North Sea. AAPG Memoir, 60: 537-571.

Ciurej A., Haczewski G. (2012) The Tylawa Limestones - a regional marker horizon in the Lower Oligocene of the Paratethys: diagnostic characteristics from the type locality. Geological Quarterly, 56 (4): 833-844.

Curtis J.B., Kotarba M.J., Lewan M.D., Więcław D. (2004) Oil/source rock correlations in the Polish Flysch Carpathians and Mesozoic basement and organic facies of the Oligocene Menilite Shales: insights from hydrous pyrolysis experiments. Organic Geochemistry, 35: 1573-1596.

Dirnerová D., Prekopová M., Janočko J. (2012) Sedimentary record of the Dukla Basin (Outer Carpathians, Slovakia and Poland) and its implications for basin evolution. Geological Quarterly, 56 (3): 547-560.

Espitalie J., Deroo G., Marquis F. (1985) La pyrolyse Rock Eval et ses applications (in French). Revue IFP, 40-41: 563-579 and 755-784.

Golonka J. (2011) Evolution of the Outer Carpathian Basins. Grzybowski Foundation, Special Publication, 17: 3-14

Hunt J.M., Lewan M.D., Hennet R.C. (1991) Modeling oil generation with time - temperature index graphs based on the Arrhenius equation. AAPG Bulletin, 75: 795-807.

Hunt J.M. (1996) Petroleum Geochemistry and Geology. W.H. Freeman and Company, New York.

Jarmolowicz-Szulc K., Karwowski Ł., Marynowski L. (2012) Fluid circulation and formation of minerals and bitumens in the sedimentary rocks of the Outer Carpathians - Based on studies on the quartz-calcite-organic matter association. Marine and Petroleum Geology, 32: 138-158.
Jarosiński M. (2005) Ongoing tectonic reactivation of the Outer Carpathians and its impact on the foreland: results of borehole breakout measurements in Poland. Tectonophysics, 41: 189-216.

Karnkowski P. (1999) Oil and gas deposits in Poland. Geos, Kraków.

Koltun Y.V. (1992) Organic matter in Oligocene Menilite Formation rocks of the Ukrainian Carpathians: palaeoenvironment and geochemical evolution. Organic Geochemistry, 18: 423-430.

Koltun Y.V., Espitalié J., Kotarba M., Roure F., Ellouz N., Kosakowski P. (1998) Petroleum generation in the Ukrainian external Carpathians and the adjacent foreland. Journal of Petroleum Geology, 21: 265-288.

Kosakowski P., Wróbel M. (2011) Burial and thermal history and hydrocarbon generation modelling of the Lower Palaeozoic source rocks in the Kraków-Rzeszów area (SE Poland). Annales Societatis Geologorum Poloniae, 81 (3): 459-471.

Kosakowski P., Więcław D., Kotarba M.J. (2009) Source rock characteristic of the selected flysch deposits in the transfrontier area of the Polish Outer Carpathians (in Polish with English summary). Geologia, 35 (4/1): 155-190.

Kosakowski P., Wróbel M., Poprawa P. (2010) Hydrocarbon generation and expulsion modelling of the lower Paleozoic source rocks in the Polish part of the Baltic region. Geological Quarterly, 54 (2): 241-256.

Köster J., Kotarba M., Lafargue E., Kosakowski P. (1998a) Source rock habitat and hydrocarbon potential of Oligocene Menilite Formation (Flysch Carpathians, Southeast Poland): an organic geochemical and isotope approach. Organic Geochemistry, 29: 543-558.

Köster J., Rospondek M., Schouten S., Kotarba M., Zubrzycki A., Sinninghe Damste J.S. (1998b) Biomarker geochemistry of a foredeep basin: the Oligocene Menilite Formation in SE Poland. Organic Geochemistry, 29: 649-669.

Kotarba M.J., Koltun Y.V. (2005) Origin and habitat of hydrocarbons of the Polish and Ukrainian parts of the Carpathian Province. AAPG Memoir, 84: 395-442.

Kotarba M.J., Peryt T.M. (2011) Geology and petroleum geochemistry of Miocene strata in the Polish and Ukrainian Carpathian Foredeep and its Palaeozoic-Mesozoic basement. Annales Societatis Geologorum Poloniae, 81 (3): 211-220.

Kotarba M.J., Więcław D., Koltun Y.V., Lewan M.D., Marynowski L., Dudok I.V. (2005) Organic geochemical study and genetic correlations between source rocks and hydrocarbons from surface seeps and deep accumulations in the Starunia area, fore-Carpathian region, Ukraine. In: Polish and Ukrainian Geological Studies (2004-2005) at Starunia - the area of discoveries of woolly rhinoceroses (ed. M.J. Kotarba): 125-145. Polish 
Geological Institute and Society of Research on Environmental Changes "GEOSPHERE", Kraków-Warszawa.

Kotarba M.J., Więcław D., Koltun Y.V., Kuśmierek J., Marynowski L., Dudok I.V. (2007) Organic geochemical study and genetic correlation of natural gas, oil and Menilite source rocks in the San and Stryi rivers region (Polish and Ukrainian Carpathians). Organic Geochemistry, 38: 1431-1456.

Kotarba M.J., Peryt T.M., Koltun Y.V. (2011) Microbial gas system and prospectives of hydrocarbon exploration in Miocene strata of the Polish and Ukrainian Carpathian Foredeep. Annales Societatis Geologorum Poloniae, 81: 523-548.

Kotlarczyk J., Leśniak T. (1990) Lower Part of the Menilite Formation and Related Futoma Diatomite Member in the Skole Unit of the Polish Carpathians. Akademia Górniczo-Hutnicza, Kraków: $1-74$.

Kotlarczyk J., Jerzmańska A., Świdnicka E., Wiszniowska T. (2006) A framework of ichthyofaunal ecostratigraphy of the Oligocene-Early Miocene strata of the Polish Outer Carpathian Basin. Annales Societatis Geologorum Poloniae, 76: 1-111.

Kruge M.A., Mastalerz M., Solecki A., Stankiewicz B.A. (1996) Organic geochemistry and petrology of oil source rocks, Carpathian Overthrust region, southeastern Poland - implications for petroleum generation. Organic Geochemistry, 24: 897-912.

Kulchytsky A.Y. (1986) Geology and environments of formation of the evaporite-bearing mollasse of Pre-Carpathian and TransCarpathian Neogene basins (in Russian). Ph. D thesis, Lviv University.

Kurovets I., Prytulka G., Shpot Y., Peryt, T.M. (2004) Middle Miocene Dashava Formation sandstones, Carpathian Foredeep, Ukraine. Journal of Petroleum Geology, 27: 373-388.

Kuśmierek J. (1990) Outline of geodynamics of central Carpathian oil basin (in Polish with English summary). Prace Geologiczne, 135.

Kuśmierek J. (1994) Evolution of the Central Carpathian oil basin quantitive interpretation. In: Geodynamic Evolution of Sedimentary Basins (eds. F. Roure, N. Ellouz, V.S. Shein, I. Skvortsov): 281-303. Proceedings of the Moscow Symposium.

Kuśmierek J., ed. (1995) Evolution and oil - and gas-bearing of the Polish Carpathians. (in Polish with English summary). Prace Geologiczne PAN, 138.

Kuśmierek J. (2010) Subsurface structure and tectonic style of the NE Outer Carpathians (Poland) on the basis of integrated 2D interpretation of geological and geophysical images. Geologica Carpathica, 61: 71-85.

Kuśmierek J., Maćkowski T. (1995) Calibration of the paleothermal regime (in Polish with English summary). Prace Geologiczne PAN, 138: 55-63.

Kuśmierek J., Halat Z., Kosakowski P., Krach J., Maćkowski T. (2001) Calibration of hydrocarbon expulsion processes; examples from the Carpathians (in Polish with English summary). Polish Journal of Mineral Resources, $3 \mathrm{spec}$. iss.: 87-113.

Lafargue E., Ellouz N., Roure F. (1994) Thrust-controlled exploration plays in the Outer Carpathians and their foreland (Poland, Ukraine and Romania). First Break, 12: 69-79.

Lewan M.D., Ruble T.E. (2002) Comparsion of petroleum generation kinetics by isothermal hydrous and nonisothermal open-system pyrolysis. Organic Geochemistry, 33: 1457-1475.

Lewan M.D., Kotarba M.J., Curtis J.B., Więcław D., Kosakowski P. (2006) Oil-generation kinetics for organic facies with Type-II and -IIS kerogen in the Menilite Shales of the Polish Carpathians. Geochimica et Cosmochimica Acta, 70: 3351-3368.

Maćkowski T., Kuśmierek J., Reicher B., Baran U., Kosakowski P., Łapinkiewicz P., Machowski G., Papiernik B., Szczygieł M., Zając A., Zych I. (2009) Two-dimensional models of the organic-matter thermal transformation and hydrocarbon expulsion in the transfrontier zone of the Polish and Ukrainian Carpathians (in Polish with English summary). Geologia, 35 (4/1): 191-222.

Malinowski M., Grad M., Guterch A., CELEBRATION 2000 Working Group (2008) Three-dimensional seismic modelling of the crustal structure between East European Craton and the
Carpathians in SE Poland based on CELEBRATION 2000 data. Geophysical Journal International, 173: 546-565.

Matyasik I. (2000) Potencjał węglowodorowy jednostki skolskiej polskich Karpat fliszowych. Ph.D. thesis, AGH-University of Science and Technology, Kraków.

Oszczypko N. (1999) From remnant oceanic basin to collision-related foreland basin - a tentative history of the Outer Western Carpathians. Geologica Carpathica, 50: 161-163.

Oszczypko N. (2006) Late Jurassic-Miocene evolution of the Outer Carpathian fold-and-thrust belt and its foredeep basin (Western Carpathians, Poland). Geological Quarterly, 50: 169-194.

Peters K.E., Cassa M.R. (1994) Applied source rock geochemistry. AAPG Memoir, 60: 93-120

Poprawa P., Malata T. (2006) Model of Late Jurassic to Early Miocene tectonic evolution of the Western Outer Carpathians (in Polish with English summary). Przegląd Geologiczny, 54: 1066-1080.

Roca E., Bessereau G., Jawor E., Kotarba M., Roure F. (1995) Pre-Neogene evolution of the Western Carpathians: constraints from the Bochnia-Tatra Mountains section (Polish Western Carpathians). Tectonics, 14: 855-873.

Salata D., Uchman A. (2012) Heavy minerals from Oligocene sandstones of the Menilite Formation of the Skole Nappe, SE Poland: a tool for provenance specification. Geological Quarterly, 56 (4): 803-820,

Sieniawska I., Aleksandrowski P., Rauch M., Koyi H. (2010) Control of synorogenic sedimentation on back and out-of-sequence thrusting: insights from analog modeling of an orogenic front (Outer Carpathians, southern Poland). Tectonics, 29: 1-23.

Sweeney J.J., Burnham A.K. (1990) Evaluation of a simple model of vitrinite reflectance based on chemical kinetics. AAPG Bulletin, 74: 1559-1570.

Sotak J. (2010) Paleoenvironmental changes of the Carpathian Flysch Sea during the transition from the Peri-Tethyan to Black Sea-type basins. Geologica Carpathica, 61: 393-418.

Świerczewska A. (2005) The interplay of the thermal and structural histories of the Magura Nappe (Outer Carpathians) in Poland and Slovakia. Mineralogia Polonica, 36: 91-144.

Świerczewska A., Tokarski A.K. (1998) Deformation bands and the history of folding in the Magura nappe, Western Outer Carpathians (Poland). Tectonophysics, 297: 73-90.

Ten Haven H.L., Lafargue E., Kotarba M. (1993) Oil/oil and oil/source rock correlations in the Carpathian Foredeep and Overthrust, south-east Poland. Organic Geochemistry, 20: 935-959.

Vialov O.S., Gavura S.P., Danysh V.V. (1988) Stratotypes of Cretaceous and Paleogene deposits of the Ukrainian Carpathians (In Ukrainian). Naukova Dumka, Kiev.

Vul M.Y., Denega B.I., Krupsky Y.Z., Nimets M.V., Svyrydenko V.G., Fedyshyn V.O. (1998) Western oil and gas-bearing region. In: Atlas of Oil and Gas Fields of Ukraine in Six Volumes. Volume 4 (eds. M.M. Ivanyuta, V.O. Fedyshyn et al.). Ukrainian Oil and Gas Academy, Lviv.

Więcław D., Kotarba M.J., Kuśmierek J., Kowalski A., Machowski G. (2008) Perpendicular changeability of source-rock indices of the Menilite Beds in selected profiles of the eastern part of Polish Outer Carpathians. Prace Instytutu Nafty i Gazu, 150: 455-460.

Więcław D., Lewan M.D., Kotarba M.J. (2010) Estimation of hydrous-pyrolysis kinetic parameters for oil generation from Baltic Cambrian and Tremadocian source rocks with Type-II kerogen. Geological Quarterly, 54 (2): 217-226.

Zuchiewicz, W., Tokarski A.K., Jarosiński M., Márton E. (2002) Late Miocene to present day structural development of the Polish segment of the Outer Carpathians. EGU Stephen Mueller Special Publication Series, 3: 185-202.

Żytko K. (1999) Correlation of the main structural units of the Western and Eastern Carpathians (in Polish with English summary). Prace Państwowego Instytutu Geologicznego, 168: 135-164. 